\title{
Assessing and modelling water use and the partition of evapotranspiration of irrigated hop (Humulus Lupulus), and relations of transpiration with hops yield and alpha-acids
}

\author{
M. Fandiño ${ }^{\mathrm{a}}$, J.L. Olmedo ${ }^{\mathrm{b}}$, E.M. Martínez ${ }^{\mathrm{a}}$, J. Valladares ${ }^{\mathrm{c}}$, P. Paredes ${ }^{\mathrm{d}}$, B.J. Rey ${ }^{\mathrm{a}}$, M. Mota ${ }^{\mathrm{d}}$, \\ J.J. Cancela ${ }^{\mathrm{a}, *}$, L.S. Pereira ${ }^{\mathrm{d}}$ \\ a GI-1716, Department of Agroforestry Engineering, University of Santiago de Compostela, Campus Universitario, 27002 Lugo, Spain \\ ${ }^{\mathrm{b}}$ Hijos de Rivera Inversiones Corporativas, A Coruña, Spain

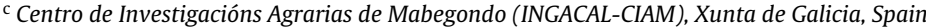 \\ ${ }^{\mathrm{d}}$ LEAF-Landscape, Environment, Agriculture and Food, Institute of Agronomy, University of Lisbon, Lisbon, Portugal
}

\section{A R T I C L E I N F O}

\section{Article history:}

Received 3 March 2015

Received in revised form 7 July 2015

Accepted 20 August 2015

\section{Keywords:}

SIMDualKc model

Hop transpiration

Dry weight cone

Alpha-acids content

Irrigation scheduling

\begin{abstract}
A B S T R A C T
This study was conducted during three seasons (2012-2014) in an experimental hop yard at Mabegondo, Galicia, NW Spain. The research aimed at calibrating and validating the soil water balance model SIMDualKc for Humulus lupulus L. cv. 'Nugget'. The model computes the soil water balance using the dual $K_{\mathrm{c}}$ approach, thus partitioning crop evapotranspiration $\left(\mathrm{ET}_{\mathrm{c}}\right)$ into crop transpiration, ground cover transpiration and soil evaporation. Calibration and validation were performed using TDR soil water content measurements, which produced small root mean square errors (RMSE) ranging from 0.012 to $0.015 \mathrm{~cm}^{3} \mathrm{~cm}^{-3}$. The initial, mid-season and end-season basal crop coefficients $\left(K_{\mathrm{cb}}\right)$ that allow computing hop transpiration were respectively $0.16,0.97$ and 0.83 . The single $K_{\mathrm{c}}$ for the same crop growth stages, which refers to transpiration and soil evaporation together, were respectively $0.69,1.02$ and 0.85 . SIMDualKc provided to estimate water use by the hop yard and the components of the soil water balance, particularly hop transpiration $\left(T_{\mathrm{Hop}}\right)$, ground covered transpiration $\left(T_{\text {cover }}\right)$ and soil evaporation $\left(E_{\mathrm{S}}\right)$. $T_{\text {Hop }}$ represented $92 \%$ of actual evapotranspiration ( $\mathrm{ET}_{\mathrm{c} \text { act }}$ ) during the mid-season, and $E_{\mathrm{s}}$ averaged $69 \%$ of $\mathrm{ET}_{\mathrm{c} \text { act }}$ during the initial stage. It was observed that $T_{\text {cover }}$ was strongly influenced by soil and ground cover management. The impacts of water use and $T_{\mathrm{Hop}}$ on hop yield quantity and quality were assessed. A linear regression between hop cone yield and $T_{\text {Hop }}$ has been found, with a high coefficient of determination $r^{2}=0.92$, while the linear regressions of $T_{\text {Hop }}$ with alpha and beta-acids had regression coefficients not significantly different from zero. These results denote appropriate irrigation management with absence of stresses that could affect yields or the concentration of bitter acids.
\end{abstract}

(c) 2015 Elsevier B.V. All rights reserved.

\section{Introduction}

Hop (Humulus lupulus L.) is an herbaceous perennial plant which female flower, also named hop cone or hops, is used in different industries. Currently the beer brewing industry accounts for $98 \%$ of the world use of hops (Zanoli and Zavatti, 2008). Hop is cultivated for its secondary metabolites, mainly bitter acids: alpha and beta-acids (Verzele, 1986). Alpha-acids are direct precursors of the main bittering principles of beer, contributing as well to the overall microbial stability (as natural preservatives), and an enhanced foam stability (Moir, 2000; Steenackers et al., 2015). They are highly

\footnotetext{
* Corresponding author.

E-mail address: javierjose.cancela@usc.es (J.J. Cancela).
}

cultivar-dependent although hops contain, on average, 9-10 wt\% of alpha-acids; however, recently developed hop cultivars may contain up to $19 \mathrm{wt} \%$ (Yakima Chief, 2013). The beta-acids are less acidic and have a more pronounced bacteriostatic action than the alphaacids. Due to their insolubility in the beer matrix (Briggs et al., 2000), the beta-acids were usually considered to be largely irrelevant for the brewing industry, besides that they may oxidize into compounds that can give beer off-flavors. However, they contribute to beer's aroma, and high beta-acid hop varieties are often used at the end of the brewing process for aroma, also because beta extract can be used as a feed for the production of bittering components, either by the transformation of the beta-acids into the synthetic isoalpha-acids or by their oxidation into the hulupones (Steenackers et al., 2015). Alpha and beta-acids could be complementary for 
bitter taste and preservative value (Schönberger and Kostelecky, 2011) in brewing industry.

Hop cones have also been used for medicinal purposes because beta-acids are a potential cancer chemopreventive or are antibacterial agents (Zanoli and Zavatti, 2008) due to its relatively high content of polyphenolic substances, with beneficial effects on health and metabolism (Čeh et al., 2007). Recently, Abram et al. (2015) reported that hops not only play a main role in the brewing industry but leaves and stems could be used as a source of antioxidant compounds for the food industry.

Several authors have shown the relevance of precipitation and temperature for an adequate growth of hop and for yield and quality, e.g., Srečec et al. $(2004,2008)$ in Croatia; Kořen (2007) and Mozny et al. (2009) in Czech Republic; Engelhard (2004) in Germany; Bavec et al. (2003) and Pavlovic et al. $(2012,2013)$ in Slovenia; Benítez et al. (1998) in Spain; and Wample and Farrar (1983) in United States. Mozny et al. (2009) reported on climate change effects concluding that hop may be a particularly vulnerable crop. In addition, various studies tackled the effects of irrigation on production at the farm scale (e.g., Wample and Farrar 1983; Svoboda et al., 2008; Delahunty et al., 2011; Nakawuka 2013) or at plant scale (Keukeleire et al., 2007; Hniličková et al., 2009; Gloser et al., 2013). These studies reported that irrigation increases yield and do not negatively affect the alpha-acid content although impacts of water and temperature stress relate with the phenological stages when occurring. This is well described by Potop (2014) who reported a low yield when drought/dryness conditions prevailed in May through August and higher yields under normal wet conditions and by Kučera and Krofta (2009) that reported that the strongest influence on the alpha-acid content was exerted by air temperatures in July and that rainfall had significant effects during the period from May to July. However, few studies have focused an in depth determination of hop water requirements (Bárek et al., 2009; Krofta et al., 2013) and there are no studies providing for an in-depth analysis of evapotranspiration or the water balance. Urban et al. (2012) applied the sap flow technique and BREB with the hop cv. 'Agnus' in Czech Republic, and Krofta et al. (2013) measured the sap flow with the hop cv. 'Premiant'. Both studies estimated hop transpiration but did not quantify soil evaporation, the actual evapotranspiration, or the components of the soil water balance.

Crop evapotranspiration $\left(\mathrm{ET}_{\mathrm{c}}\right)$ is commonly estimated using the crop coefficient approach, i.e., $\mathrm{ET}_{\mathrm{c}}=\mathrm{K}_{\mathrm{c}} \mathrm{ET}_{\mathrm{o}}$, where $K_{\mathrm{c}}$ is the crop coefficient and $\mathrm{ET}_{\mathrm{O}}$ is the reference evapotranspiration (Allen et al., 1998). Adopting the dual $K_{\mathrm{c}}$ approach $\left(K_{\mathrm{c}}=K_{\mathrm{cb}}+K_{\mathrm{e}}\right)$, where $K_{\mathrm{cb}}$ is the basal crop coefficient relative to crop transpiration and $K_{\mathrm{e}}$ is the soil evaporation coefficient, it is possible to partition $\mathrm{ET}_{\mathrm{c}}$ into hop transpiration $\left(T_{\mathrm{Hop}}=K_{\mathrm{cb}} \mathrm{ET}_{0}\right)$ and soil evaporation $\left(E_{\mathrm{S}}=K_{\mathrm{e}} \mathrm{ET}_{\mathrm{o}}\right)$ as described by Allen et al. (1998, 2005) and Rosa et al. (2012a,b). Initial, mid-season and end-season single and basal $K_{\mathrm{c}}$ for hop are tabled by Allen et al. $(1998,2007)$, which allow to draw the $K_{\mathrm{c}}$ (and $K_{\mathrm{cb}}$ ) curves relative to the full crop season. The dual $K_{\mathrm{c}}$ approach requires a daily soil water balance for determination of the actual evapotranspiration and a daily water balance of the upper soil layer from where soil evaporation originates for determination of $K_{\mathrm{e}}$. This requirement gives higher precision to computations using the dual $K_{\mathrm{c}}$ approach relative to using the single $K_{\mathrm{c}}$ but the computational procedures are quite demanding and a model like SIMDualKc (Rosa et al., 2012a,b) is then needed.

Several methods and techniques may be applied to measure and estimate crop evapotranspiration, e.g., lysimeters, heat pulse, heat balance, Bowen ratio energy balance (BREB), surface renewal energy balance, eddy covariance and the soil water balance (Allen et al., 2011). The selection of the methods to be used relate with the objectives of the study and the complexity of the ecosystem to be observed. Relative to the intended hop cropped area the objectives of the study were to determine hop transpiration and soil evaporation in an irrigated plantation with active ground cover in the inter-row and where capillary rise from a shallow water table could contribute to evapotranspiration. There was no intention of analysing the various hydrologic processes involved but to estimate water use and consumption aiming at supporting improved irrigation management with consideration of water-yield interactions. Thus it was selected a simple but accurate approach that allowed the calibration and use of the referred water balance model SIMDualKc. Otherwise a soil water flux model would be required that would be able to compute the up-and downward fluxes through the root zone bottom, which could also consider a multi domain ET referring to the crop, the soil and the understory vegetation, and that would be able to accurately separate crop transpiration and soil evaporation. This approach, in addition to measurements of ET (Allen et al., 2011), would require observation of soil water potential in addition to soil water content to describe the dynamics of water in the root zone (e.g., Cameira et al., 2005; Liu et al., 2006; Ma et al., 2013), or the use of tracers to detect the water originated from the water table (Grünberger et al., 2011), or the use of water table lysimeters (Luo and Sophocleous, 2010). The approach would need the use of mini and/or micro-lysimeters to estimate the evapotranspiration from the understory vegetation and the evaporation from the soil with and without mulching (Yunusa et al., 2004; Centinari et al., 2012), the use of sap flow devices to estimate the transpiration fluxes from a sample of hop plants and/or the use of some isotopic approaches to identify the origin of water vapour (Williams et al., 2004; Rothfuss et al., 2010; Sutanto et al., 2012). That complex, costly and labour demanding approach cannot be justified for a study aimed at simply assessing water use dynamics of a hop plantation aimed at improved irrigation. The alternative was to adopt a simpler field research approach that would allow to calibrate and further use the SIMDualKc model that has proved able to simulate the dynamics of the soil water content of a plantation taking into consideration the impacts of a shallow water table (e.g., Rosa et al., 2012b; Wu et al., 2015), to partition ET into crop transpiration and soil evaporation using the dual $K_{\mathrm{c}}$ approach (e.g., Paço et al., 2012, 2014; Zhao et al., 2013; Zhang et al., 2013; Wei et al., 2015), and to consider the effects of understory vegetation (Fandiño et al., 2012; Cancela et al., 2015). Moreover, the application of the model responds to requisites of calibration and validation, including the determination of related errors and other goodness-of-fit indicators (Pereira et al., 2015) and results are assessed comparatively to other studies aiming at better basing related analysis.

Considering the good results obtained with the SIMDualKc model in former applications and its ability to simulate water use by a crop under conditions of variable water table depth and variable inter-row soil cover, SIMDualKc was selected to fill the knowledge gap on water use by hop plantations, on hop evapotranspiration and its partition into $\mathrm{T}_{\mathrm{Hop}}$ and $\mathrm{E}_{\mathrm{s}}$. Thus, the main objectives of the present study are: (i) to calibrate and validate the soil water balance model SIMDualKc for the hop cv 'Nugget' in Galicia; (ii) to determine hop transpiration and soil evaporation during the crop seasons of 2012-2014; (iii) to compute the water balance components of hop fields, including groundwater contribution and active ground cover transpiration; and (iv) to assess the impacts of crop transpiration on hop yield quantity and quality, mainly the alpha acids.

\section{Materials and methods}

\subsection{Site description and meteorological data}

The study was conducted during three seasons (2012-2014) in an experimental hop yard at the 'Centro de Investigacións Agrarias de Mabegondo' (CIAM), located in Mabegondo, Galicia, NW Spain $\left(43^{\circ} 14^{\prime} 3.7^{\prime \prime} \mathrm{N}, 8^{\circ} 15^{\prime} 12.9^{\prime \prime} \mathrm{W}\right.$ and $60 \mathrm{~m}$ elevation a.s.l.). The field 
is about 1 ha and is nearly flat. The crop was established in 2007 and was planted with spacing $3.0 \mathrm{~m} \times 2.0 \mathrm{~m}$; the plant density was 1667 plants ha ${ }^{-1}$ and the trellis were $6.0 \mathrm{~m}$ high. Plantation has the East-West orientation (Olmedo, 2011). The study field was divided into two plots corresponding to different drip irrigation sectors. Plot 1 refers to the lower part of the field, close to a small river, and Plot 2 is in the upper part of the field.

Soils are silt loam with an average of $33.7 \%$ sand, $46.7 \%$ silt and $19.6 \%$ clay; the organic matter content averages $6.7 \%$. The total available soil water (TAW) down to $0.8 \mathrm{~m}$ depth was 168 and $160 \mathrm{~mm}$ in Plot 1 and Plot 2, respectively, which was calculated from the difference between the field capacity $\left(\theta_{\mathrm{FC}}=0.38 \mathrm{~cm}^{3} \mathrm{~cm}^{-3}\right)$ and the permanent wilting point $\left(\theta_{\mathrm{WP}}=0.18 \mathrm{~cm}^{3} \mathrm{~cm}^{-3}\right.$ for Plot 1 and $0.17 \mathrm{~cm}^{3} \mathrm{~cm}^{-3}$ for Plot 2$)$. Soil water content at saturation $\left(\theta_{\text {Sat }}\right)$ was $0.42 \mathrm{~cm}^{3} \mathrm{~cm}^{-3}$, for both plots.

The climate is of Atlantic type. The Köppen-Geiger classification is Csb, i.e., a warm temperate climate with dry and warm summer (Kottek et al., 2006). Agrometeorological data were obtained from the CIAM station, located a few hundred meters away of the field. Daily data consisted of maximum and minimum temperature ( $T_{\max }$ and $\left.T_{\min },{ }^{\circ} \mathrm{C}\right)$, wind speed at $2 \mathrm{~m}$ height $\left(u_{2}, \mathrm{~m} \mathrm{~s}^{-1}\right)$ and rainfall for the period 2012-2014 (Fig. 1). During the period March-September of 2012 the monthly average $T_{\max }$ and $T_{\min }$ ranged between 13.9 and $25.2^{\circ} \mathrm{C}$ and 3.6 and $13.2^{\circ} \mathrm{C}$, respectively. In 2013 those monthly temperatures were slightly higher, with $T_{\max }$ ranging $14.5-27.2^{\circ} \mathrm{C}$ and $T_{\min }$ ranging $5.9-13.7^{\circ} \mathrm{C}$, while in 2014 the monthly $T_{\max }$ and $T_{\text {min }}$ varied respectively $17.3-26.1^{\circ} \mathrm{C}$ and $5.2-13.4^{\circ} \mathrm{C}$. Thus, monthly temperatures were quite similar in the three crop seasons and no hot waves were observed. $\mathrm{ET}_{\mathrm{o}}$ was computed with the FAO Penman-Monteith equation using limited weather data, i.e., estimating the actual vapour pressure from the daily minimum temperature and solar radiation from daily maximum and minimum temperature (Allen et al., 1998). This method was tested for similar climates by Cancela et al. (2015) in Galicia.

Daily precipitation and $\mathrm{ET}_{\mathrm{o}}$ for March to September during the three years of study are presented in Fig. 1, which shows that precipitation in 2012 was concentrated in April and May while July to September was a dry period. Differently, rainfall in 2013 was concentrated in March-April but July to September were also dry months. In 2014 precipitation was more evenly distributed. $\mathrm{ET}_{0}$ shows to be higher in the summer months where it may attain $6 \mathrm{~mm} \mathrm{~d}^{-1}$. However, its daily variability is high following the natural variability of radiation, temperature, and wind speed. $\mathrm{ET}_{0}$ was quite similar during the three crop seasons, higher in 2014 $(603 \mathrm{~mm})$ and lower in $2013(543 \mathrm{~mm})$.

\subsection{Modelling approach-the SIMDualKc model}

SIMDualKc (Rosa et al., 2012a) is a soil water balance model aimed at assessing crop water use and requirements and to support irrigation scheduling and management at field scale. The model adopts the dual $K_{\mathrm{c}}$ approach (Allen et al., 1998, 2005) for partitionning crop evapotranspiration into soil evaporation $\left(E_{\mathrm{s}}\right)$ and crop transpiration $\left(T_{\mathrm{C}}\right)$

$\mathrm{ET}_{\mathrm{c}}=\left(K_{\mathrm{cb}}+K_{\mathrm{e}}\right) \mathrm{ET}_{\mathrm{o}}$

where $\mathrm{ET}_{\mathrm{c}}$ is crop evapotranspiration $\left[\mathrm{mm} \mathrm{d}^{-1}\right], K_{\mathrm{cb}}$ is the basal crop coefficient [], $K_{\mathrm{e}}$ is the soil evaporation coefficient [] and $\mathrm{ET}_{\mathrm{o}}$ is the grass reference crop evapotranspiration $\left[\mathrm{mm} \mathrm{d}^{-1}\right]$, thus resulting $T_{\mathrm{c}}=K_{\mathrm{cb}} \mathrm{ET}_{\mathrm{o}}$ and $E_{\mathrm{s}}=K_{\mathrm{e}} \mathrm{ET}_{\mathrm{o}}$. The dual Kc approach is often used due to its good practical performance as analyzed by Kool et al. (2014). Applications refer not only to soil water balance models but also to mechanistic models (Forkutsa et al., 2009; Ramos et al., 2012; González et al., 2015). The approach has been verified from observations of $T_{\mathrm{C}}$ and/or $E_{\mathrm{S}}$ by Paço et al. $(2012,2014)$, Cammalleri et al. (2013), Ding et al. (2013), Zhao et al. (2013) and Wei et al. (2015).
To consider the influence of crop density and height on $K_{\mathrm{cb}}$ the model uses the effective fraction of ground covered or shaded by the vegetation $\left(f_{\text {c eff }}\right)$ and the crop heigh $(h)$ considering a crop density coefficient $\left(K_{\mathrm{d}}\right)$ (Allen et al., 2007; Allen and Pereira, 2009):

$K_{\mathrm{d}}=\min \left(1, M_{\mathrm{L}} f_{\mathrm{ceff}} f_{\text {ceff }}^{\frac{1}{1+\mathrm{h}}}\right)$

where the $M_{\mathrm{L}}$ parameter [] is a multiplier of $f_{\mathrm{c} \text { eff }}$ representing the maximum ratio of ET per fraction of ground shaded. $f_{c \text { eff }}$ differs from the fraction of soil surface covered by vegetation $\left(f_{\mathrm{c}}\right)$ due to the combined effect of the canopy shape, plant height and solar angle above the horizon on the shaded area (Allen and Pereira, 2009; Rosa et al., 2012a). In incomplete cover crops, such as orchards, vineyards and hop plantations, an active ground cover may occur that competes with the crop for the available soil water and contributes to the total evapotranspiration. Thus, the following approach is adopted in SIMDualKc (Allen and Pereira, 2009; Rosa et al., 2012a) for estimating $\mathrm{K}_{\mathrm{cb}}$ :

$K_{\mathrm{cb}}=K_{\mathrm{cb} \text { cover }}+K_{\mathrm{d}}\left(\max \left[K_{\mathrm{cb} \text { full }}-K_{\mathrm{cb} \text { cover }}, \frac{K_{\mathrm{cb} \text { full }}-K_{\mathrm{cb} \text { cover }}}{2}\right]\right)(3)$

where $K_{\mathrm{cb} \text { cover }}$ is the $K_{\mathrm{cb}}$ of the active ground cover in the absence of tree foliage, $K_{\mathrm{d}}$ is the crop density factor (Eq. (2)), and $K_{\mathrm{cb} \text { full }}$ is the basal $K_{\mathrm{cb}}$ for the crop under full cover (or LAI > 3) conditions and corrected for climate, with all coefficients non-dimensional. To take into account the effects of shading of the active ground cover by the taller plants the second term of the max function reduces the estimated $K_{\mathrm{cb}}$ by half the difference between $K_{\mathrm{cb} \text { full }}$ and $K_{\mathrm{cb} \text { cover }}$ This approach is already tested for vineyards (Fandiño et al., 2012; Cancela et al., 2015), peach orchards (Paço et al., 2012) and olives (Paço et al., 2014). The $K_{\mathrm{cb} \text { cover }}$ reflects the density and vigor of the surface cover; it changes with soil management practices, e.g., tillage operations and application of herbicides. The model estimates $K_{\mathrm{cb} \text { cover }}$ using field observed data, such as the fraction of the active ground cover, its density and its height. Detailed information on the ground cover management on hop fields along the seasons is provided in Appendix 1.

In SIMDualKc (Rosa et al., 2012a) $E_{\mathrm{s}}$ is computed performing a daily water balance of the upper soil layer from where most of water evaporates. The evaporation layer, of thickness $Z_{\mathrm{e}}(\mathrm{m})$, is characterized by the total evaporable water (TEW, $\mathrm{mm}$ ), that is the maximum depth of water that can be evaporated from that layer when it has been completely wetted, and the readily evaporable water (REW, mm), which is the depth of water that can be evaporated without water restrictions (Allen et al., 1998, 2005). TEW and REW are estimated from the soil textural and hydraulic characteristics, respectively. $E_{\mathrm{s}}$ is limited by the amount of energy available at the soil surface combined with the energy consumed by transpiration (Allen et al., 1998, 2007) and its value cannot exceed the difference $K_{\mathrm{c} \max }-K_{\mathrm{cb}}$, with $K_{\mathrm{c} \max }=\max \left(K_{\mathrm{cb}}+K_{\mathrm{e}}\right)$. As the topsoil dries and less water is available for evaporation a reduction of $E_{\mathrm{s}}$ occurs in proportion to the amount of water remaining in the surface soil layer; thus, $K_{\mathrm{e}}$ becomes

$K_{\mathrm{e}}=K_{\mathrm{r}}\left(K_{\mathrm{c} \max }-K_{\mathrm{cb}}\right)$ with $K_{\mathrm{e}} \leq f_{\mathrm{ew}} K_{\mathrm{c} \max }$

where $K_{\mathrm{r}}$ is the evaporation reduction coefficient $(\leq 1.0), K_{\mathrm{c} \max }$ is the maximum value of $K_{\mathrm{c}}$ following a rain or an irrigation event, and $f_{\text {ew }}$ is the fraction of the soil that is both exposed and wetted. SIMDualKc computes $K_{\mathrm{r}}$ using the 2 -stage drying cycle (Ritchie, 1972; Allen et al., 1998), where the first stage is an energy limited stage, and the second is a water limited stage with evaporation decreasing as evaporable water is depleted in the evaporation soil layer beyond REW, thus

$K_{\mathrm{r}}=1 \quad$ for $D_{\mathrm{e}, \mathrm{i}-1} \leq \mathrm{REW}$ 

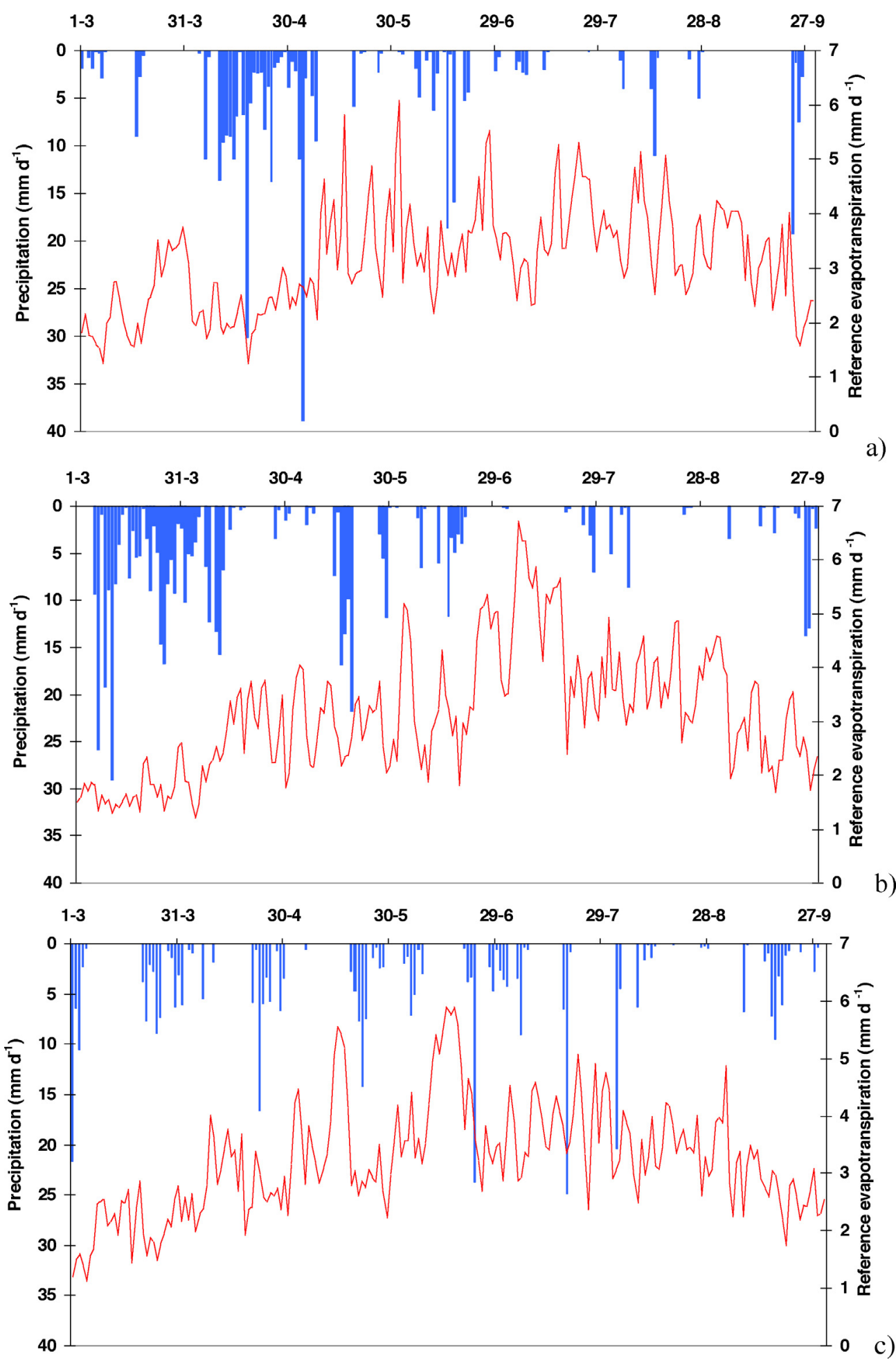

Fig. 1. Total daily precipitation (_ ) and reference evapotranspiration (_ $($ ) in the experimental area: (a) 2012 , (b) 2013 and (c) 2014.

$K_{\mathrm{r}}=\frac{\mathrm{TEW}-D_{\mathrm{e}, \mathrm{i}-1}}{\mathrm{TEW}-\mathrm{REW}}$ for $D_{\mathrm{e}, \mathrm{i}-1}>\mathrm{REW}$

SIMDualKc adjusts $K_{\mathrm{e}}$ to the fraction of ground cover by both the crop and active vegetation to estimate the fraction of soil from which most evaporation occurs and that is both exposed to radiation and wetted by rain and irrigation. When the ground cover is not active due to herbicides application (see Appendix 1), the vegetation residues on the soil act as a mulch, hence reducing soil evaporation, which is considered by the model as described by Rosa et al. (2012a). Impacts of mulch on $E_{\mathrm{s}}$ were tested by Martins et al. (2013) using SIMDualKc. The model performs a daily soil water balance to the depth of the root zone expressed in terms of depletion at the end of the day $\mathrm{i}\left(D_{\mathrm{i}}, \mathrm{mm}\right)$ as follows:

$D_{\mathrm{i}}=D_{\mathrm{i}-1}(P-\mathrm{RO})_{\mathrm{i}}-\mathrm{I}_{\mathrm{i}}-\mathrm{CR}_{\mathrm{i}}+\mathrm{ET}_{\mathrm{cact}, \mathrm{i}}+\mathrm{DP}_{\mathrm{i}}$

here $D_{\mathrm{i}-1}$ is the depletion at the preceding day, $P$ is precipitation, I is irrigation, CR is capillary rise from a shallow water table, DP is deep percolation out of the root zone and $\mathrm{RO}$ is runoff, with all terms expressed in $\mathrm{mm}$. 
The actual crop ET (ET $\mathrm{E} \mathrm{act}_{\mathrm{mm}}$ ) is computed as a function of the available soil water in the root zone using a water stress coefficient $\left(K_{\mathrm{s}}, 0-1\right) . \mathrm{K}_{\mathrm{s}}$ is expressed as a linear function of the cumulative depletion in the effective root zone $\left(D_{\mathrm{r}}\right)$ following Allen et al. (1998, 2005):

$K_{\mathrm{s}}=\frac{\mathrm{TAW}-D_{\mathrm{r}}}{\mathrm{TAW}-\mathrm{RAW}}=\frac{\mathrm{TAW}-D_{\mathrm{r}}}{(1-p) \mathrm{TAW}}$ for $D_{\mathrm{r}}>$ RAW

$K_{\mathrm{S}}=1$ for $D_{\mathrm{r}} \leq \mathrm{RAW}$

where TAW and RAW are, respectively, the total and readily available soil water $(\mathrm{mm})$ relative to the root zone depth, $Z_{\mathrm{r}}$, and $p$ is the soil water depletion fraction for no stress (dimensionless), which corresponds to the depletion threshold beyond it the crop is water stressed. The $p$ value varies with the crop, variety and environmental conditions, mainly the evaporative demand of the atmosphere (Allen et al., 1998). RAW is therefore defined as

$\mathrm{RAW}=p \mathrm{TAW}$

Considering what explained above, the model computes actual evapotranspiration as:

$\mathrm{ET}_{\mathrm{c} \mathrm{act}}=T_{\text {Hop act }}+T_{\text {cover }}+E_{\mathrm{S}}$

where $T_{\text {Hop act }}=K_{\mathrm{s}} K_{\mathrm{cb} \text { Hop }} \mathrm{ET}_{\mathrm{o}}$ is actual hop crop transpiration, $T_{\text {cover }}=K_{\mathrm{cb} \text { cover }} \mathrm{ET}_{\mathrm{o}}$ is the transpiration from an active ground cover, and $E_{\mathrm{S}}=K_{\mathrm{e}} \mathrm{ET}_{\mathrm{o}}$ is soil evaporation.

The daily capillary rise and deep percolation fluxes are estimated with the parametric equations developed by Liu et al. (2006). The actual CR fluxes $\left(\mathrm{mm} \mathrm{d}^{-1}\right)$ are estimated using data on the actual water table depth $\left(D_{\mathrm{w}}, \mathrm{m}\right)$, actual soil water storage $\left(W_{\mathrm{a}}\right.$, $\mathrm{mm})$, potential crop evapotranspiration $\left(\mathrm{ET}_{\mathrm{c}}, \mathrm{mmd}^{-1}\right)$ and maximum capillary rise $\left(\mathrm{CR}_{\max }, \mathrm{mmd}^{-1}\right)$. The actual daily $\mathrm{CR}$ flux is computed proportionally to $\mathrm{CR}_{\max }$ depending upon $\mathrm{ET}_{\mathrm{c}}, D_{\mathrm{w}}$ and $W_{\mathrm{a}}$. CR reduces relative to $\mathrm{CR}_{\max }$ when the root zone storage $W_{\mathrm{a}}$ is high, or the depth $D_{\mathrm{w}}$ of the water table increases, and/or $\mathrm{ET}_{\mathrm{c}}$ decreases. The parameters relative to water storage $\left(a_{1}, b_{1}, a_{2}, b_{2}\right)$, to the relationships between $D_{\mathrm{w}}$ and $\mathrm{ET}_{\mathrm{c}}\left(a_{3}, b_{3}\right)$, and to the $\mathrm{CR}_{\max }$ calculation $\left(a_{4}, b_{4}\right)$ need to be calibrated taking into consideration the actual soil and water table characteristics (Rosa et al., 2012b; Wu et al., 2015). Liu et al. (2006) proposed sets of parameter values for silty, silt loam and sandy loam soils that may be used as default values. The DP flux $\left(\mathrm{mm} \mathrm{d}^{-1}\right)$ is computed using a time decay function relating the soil water storage near saturation with the time after the occurrence of a heavy rain or irrigation (Liu et al., 2006). The corresponding parameters $\left(a_{\mathrm{D}}, b_{\mathrm{D}}\right)$ also need to be calibrated.

The surface runoff generated when rainfall exceeds infiltration is simulated in SIMDualKc using the curve number $(\mathrm{CN})$ method (USDA-SCS, 1972). The parameter CN relates to soil, vegetation, and actual soil water storage and may be estimated using tabled values (Allen et al., 2007). This method is commonly used in soil water balance modeling (e.g., Raes et al., 2006; Luo et al., 2008).

The input data requirements of the SIMDualKc model include:

i. Daily climatic data: reference evapotranspiration $\left(\mathrm{ET}_{0}, \mathrm{~mm}\right)$, precipitation $(P, \mathrm{~mm})$, maximum and minimum temperature ( $T_{\max }$ and $\left.T_{\min },{ }^{\circ} \mathrm{C}\right)$, minimum relative humidity $\left(\mathrm{RH}_{\min }, \%\right)$, and wind speed at $2 \mathrm{~m}$ height $\left(u_{2}, \mathrm{~m} \mathrm{~s}^{-1}\right)$.

ii. Soil data for a multi-layered soil: number of layers and layer depths, $d(\mathrm{~m})$, the respective soil water content at field capacity and the wilting point $\left(\theta_{\mathrm{FC}}\right.$ and $\left.\theta_{\mathrm{WP}}, \mathrm{cm}^{3} \mathrm{~cm}^{-3}\right)$ or the total available water in the root zone (TAW, $\mathrm{mm}$ ); the characteristics of the soil evaporation layer $\left(Z_{\mathrm{e}}, \mathrm{REW}\right.$ and TEW); and the soil water content at planting in both the root zone and the evaporation layer expressed as a \% of TAW and TEW, respectively.

iii. Crop data: dates of the initial, crop development, mid-season, and late season crop stages; the basal crop coefficients for the initial, mid-season and end season ( $K_{\mathrm{cb} \text { ini }}, K_{\mathrm{cb} \text { mid }}$, and $\left.K_{\mathrm{cb} \text { end }}\right)$; the soil water depletion fractions for no stress at the same stages $\left(p_{\text {ini }}, p_{\text {mid }}\right.$ and $\left.p_{\text {end }}\right)$; root depths $\left(Z_{r}, m\right)$, plant height $(h, m)$, and the fraction of ground cover by the crop $\left(f_{c}, \%\right)$ throughout the crop season.

iv. Irrigation scheduling data: dates and depths of observed irrigation events or the soil water thresholds and preferred irrigation depths and frequency when the model is used to generate irrigation schedules for the field practice.

v. Irrigation parameters influencing soil evaporation: the fraction of soil wetted by irrigation $\left(f_{\mathrm{w}}\right)$, and the fraction of soil wetted and exposed to radiation $\left(f_{\mathrm{ew}}\right)$. In the current study, $f_{\mathrm{ew}}=1-f_{\mathrm{c}}$ and, because the soil was partially wetted by drip irrigation, $f_{\mathrm{w}}$ was 0.05 .

vi. Parameters required by the parametric equations used to compute capillary rise and deep percolation as referred above.

vii. Base data to estimate impacts of active ground cover, effects of soil mulches and to assess surface runoff with the $\mathrm{CN}$ method.

\subsection{Calibration and validation procedures and accuracy indicators}

In the present study, model calibration was assumed as the process of "adjusting influential model parameters and inputs within their reasonable ranges so that the model results are realistic and/or consistent with available observed data"; model validation was considered as the process of evaluating the accuracy of the model estimations using the calibrated parameters with independent observed data sets (Moriasi et al., 2007; Wang et al., 2012; Pereira et al., 2015).

The calibration of the model was performed by adjusting the crop parameters (basal crop coefficients, $K_{\mathrm{cb}}$, and depletion fractions for no stress, $p)$, the soil evaporation parameters $\left(Z_{\mathrm{e}}\right.$, TEW, REW), and the parameters relative to the DP, CR and RO through minimizing the residual deviations between simulated and observed soil water content. A trial and error procedure was used as detailed by Pereira et al. (2015). The initial values of parameters were: $K_{\mathrm{cb}}$ and $p$ as tabled by Allen et al. (1998), $Z_{\mathrm{e}}$, TEW and REW estimated according to Allen et al. (1998, 2005), DP and CR parameters as proposed by Liu et al. (2006) for sandy-loam soils, and $\mathrm{CN}$ as tabled by Allen et al. (2007). The first iterations aimed at improving the $K_{\mathrm{cb}}$ and $p$ values and the following iterations also considered the soil evaporation parameters; later, the DP, CR and $\mathrm{CN}$ parameters were optimized, and finally all parameters were adjusted again. The trial and error procedure was ended when differences between simulated and observed soil water content (SWC) values were minimized and did not change from an iteration to the next. The calibration was performed using data from Plot 1 in 2013. Validation of the model was performed for all the remaining data sets using the parameters obtained from the calibration.

The evaluation and discussion of the model application was performed using goodness-of-fit indicators (Moriasi et al., 2007; Wang et al., 2012; Pereira et al., 2015). To assess the accuracy of model predictions, several approaches were used in addition to analysing the graphical time dependent representations of model-simulated vs. observed SWC that was used during the trial and error procedure. The first approach was the linear regression between observed and model-predicted SWC forced to the origin, which regression coefficient is

$$
b_{0}=\left[\frac{\sum_{i=1}^{n} O_{i} P_{i}}{\sum_{i=1}^{n} O_{i}^{2}}\right]
$$


and the ordinary least squares regression which coefficient of determination is:

$$
r^{2}=\left\{\frac{\sum_{i=1}^{n}\left(O_{i}-\bar{O}\right)\left(P_{i}-\bar{P}\right)}{\left[\sum_{i=1}^{n}\left(O_{i}-\bar{O}\right)^{2}\right]^{0.5}\left[\sum_{i=1}^{n}\left(P_{i}-\bar{P}\right)^{2}\right]^{0.5}}\right\}^{2}
$$

where $O_{i}$ and $P_{i}(i=1,2, \ldots, n)$ represent pairs of observed and predicted values for a given variable, and $\bar{O}$ and $\bar{P}$ are the respective mean values. When $b_{0}$ is close to 1.0 the covariance is close to the variance of the observed values, indicating that predicted and observed values are statistically similar. A $r^{2}$ close to 1.0 indicates that most of the total variance of the observed values was explained by the model.

In addition, a set of indicators considering the residual estimation errors was also used (Moriasi et al., 2007; Pereira et al., 2015):

a.) The root mean square error (RMSE), which characterizes the variance of the errors and is expressed in the same units as the observed values $O_{i}$ :

RMSE $=\left[\frac{\sum_{i=1}^{n}\left(O_{i}-P_{i}\right)^{2}}{n}\right]^{0.5}$

b.) The ratio RSR of the RMSE to the standard deviation of observed data (sd) that standardizes RMSE using the sd of observations, with RSR values close to 0.0 indicating a good simulation performance;

$$
\mathrm{RSR}=\frac{\left[\sum_{i=1}^{n}\left(O_{i}-P_{i}\right)^{2}\right]^{0.5}}{\left[\sum_{i=1}^{n}\left(O_{i}-\bar{P}\right)^{2}\right]^{0.5}}
$$

c.) The average absolute error (AAE), which expresses the size of the estimation errors, in the same units as $O_{i}$ :

$$
\mathrm{AAE}=\frac{1}{n} \sum_{i=1}^{n}\left|O_{i}-P_{i}\right|
$$

d.) The average relative error (ARE), which indicates the size of errors in relative terms and is expressed as a percentage:

$$
\mathrm{ARE}=\frac{100}{n} \sum_{i=1}^{n}\left|\frac{O_{i}-P_{i}}{O_{i}}\right|
$$

e.) The percent bias (PBIAS) that measures the average tendency of the simulated data to be larger or smaller than their corresponding observations, with low values indicating an accurate model simulation; positive or negative values refer to the occurrence of an under- or over-estimation bias.

$$
\text { PBIAS }=100 \frac{\sum_{i=1}^{n}\left(O_{i}-P_{i}\right)}{\sum_{i=1}^{n} O_{i}}
$$

f.) The modeling efficiency, EF, a normalized statistic developed by Nash and Sutcliffe (1970) that determines the relative magnitude of the residual variance compared to the measured data variance:

$$
\mathrm{EF}=1.0-\frac{\sum_{i=1}^{n}\left(O_{i}-P_{i}\right)^{2}}{\sum_{i=1}^{n}\left(O_{i}-\bar{O}\right)^{2}}
$$

EF close to 1.0 indicates that the residual variance is much smaller than the measured data variance, thus an excellent simulation performance. Contrarily, a null or negative value for EF indicates that the simulation is poor and that using the mean of observations is as good as the model.

\section{Results and discussion}

\subsection{Field observation results}

In 2012 two treatments were considered: Plot 1 was rain-fed and Plot 2 was irrigated. In 2013 and 2014 both plots were irrigated with different irrigation depths. The seasonal irrigation depths are shown in Table 2. Irrigation started by early July and ended a few days before harvest, in September. Generally, the interval between irrigation events was four days. Surface drip irrigation was used. The lateral pipes were equipped with in-line non-compensating emitters spaced by $50 \mathrm{~cm}$ along the crop row, thus resulting in four emitters per plant; the emitters flow rate was $2 \mathrm{Lh}^{-1}$. To assess the variability of discharges along the laterals, field evaluations were performed. Net application depths varied 3.9-9.9 $\mathrm{mm}$.

During the three crop seasons studied, the dates of the phenological stages were determined according to the $\mathrm{BBCH}$ system (Rossbauer et al., 1995). These BBCH phenological dates were later converted into the FAO standard crop growth stages (Allen et al., $1998)$ for building the crop coefficient $\left(K_{\mathrm{c}}\right.$ and $\left.K_{\mathrm{cb}}\right)$ curves: the initial stage (that refers to $K_{\mathrm{c} \text { ini }}$ or $K_{\mathrm{cb} \text { ini }}$ ) starts at plant initiation and ends at formation of side shoots (BBCH stage 2); the crop development stage is from there until flowering (stage 6); the mid-season stage $\left(K_{\mathrm{c} \text { mid }}\right.$ or $\left.K_{\mathrm{cb} \text { mid }}\right)$ includes flowering and the development of cones (stage 7); the late season is from then until maturity/harvest (stage 8 ); the end season ( $K_{\mathrm{c} \text { end }}$ or $\left.K_{\mathrm{cb} \text { end }}\right)$ is at harvesting. The dates limiting each crop growth stage are given in Table 1 for the three crop seasons; they varied much during the initial and crop development periods due to the variability of related weather conditions, but that variability decreased after the start of the mid-season. No differences were observed between plots.

Crop data was collected/observed in six plants per plot, within eight rows per plot and two replications of three plants in each plot. Crop heights were observed throughout the seasons and their values at the dates of the crop growth stages are presented in Table 1. The crop attained a maximum height of $6.0 \mathrm{~m}$, which related to the adopted trellis system. The effective root depth was $0.80 \mathrm{~m}$ as observed in the field. The fraction of ground covered/shaded by the crop $\left(f_{\mathrm{c}}\right)$, that was used to compute the crop transpiration and evaporation from $f_{\mathrm{c}}$ and height as proposed by Allen and Pereira (2009), was measured during the three seasons with help of photos taken near the solar noon in sunshine days to well observe the shadow produced by the crop. The maximum hop cover near solar noon ranged $8-9 \%$ of the cropped area depending on the maximum vegetative development achieved.

Observations of the active ground cover, mainly natural herbaceous vegetation and rapeseed in the inter-row area, were performed throughout all crop seasons and included the respective density, height and fraction of surface cover. These data are given in Appendix 1 referring to the dates of related ground cover management operations and were used as model input to properly performing the partition of actual evapotranspiration.

The soil water content (SWC) was monitored with a TDR100 (Campbell Scientific, USA), which operates in the field using the software PCTDR (Souto et al., 2008). TDR used waveguide stainless steel of $0.80 \mathrm{~m}$ length integrating SWC to the root zone. The equation of Topp et al. (1980) relating the volumetric water content with the measured bulk dielectric constant was used since it proved appropriate for soils that do not contain substantial amounts of bound water, e.g., most sandy and loamy soils (Robinson et al., 2003). The SWC was measured in 12 stations per plot; observations were performed to a depth of $0.80 \mathrm{~m}$. Measurements were 
Table 1

Hop growth stages dates, and respective crop height (h) and fraction of ground cover by the crop $\left(f_{\mathrm{c}}\right), 2012-2014$ seasons.

\begin{tabular}{|c|c|c|c|c|c|c|c|c|c|}
\hline \multirow[t]{2}{*}{ Crop growth stages } & \multicolumn{3}{|l|}{2012} & \multicolumn{3}{|l|}{2013} & \multicolumn{3}{|l|}{2014} \\
\hline & Dates & $\mathrm{h}(\mathrm{m})$ & $f_{\mathrm{c}}$ & Dates & $\mathrm{h}(\mathrm{m})$ & $f_{\mathrm{c}}$ & Dates & $\mathrm{h}(\mathrm{m})$ & $f_{\mathrm{c}}$ \\
\hline Initiation & 22 March & 0.01 & 0.01 & 15 April & 0.01 & 0.01 & 11 March & 0.05 & 0.01 \\
\hline Start rapid growth & 10 May & 0.10 & 0.04 & 19 May & 0.15 & 0.05 & 20 April & 0.15 & 0.04 \\
\hline Start mid-season & 15 July & 5.00 & 0.08 & 30 July & 5.50 & 0.09 & 10 July & 6.00 & 0.08 \\
\hline Start maturity & 15 August & 6.00 & 0.08 & 25 August & 6.00 & 0.09 & 10 August & 6.00 & 0.08 \\
\hline Harvesting & 11 September & 6.00 & 0.08 & 13 September & 6.00 & 0.09 & 04 September & 6.00 & 0.08 \\
\hline
\end{tabular}

Table 2

Treatments applied in all seasons and locations. Irrigation and rainfall depths.

\begin{tabular}{|c|c|c|c|c|c|}
\hline Year & Location & Treatment & $\begin{array}{l}\text { Number of } \\
\text { irrigations }\end{array}$ & $\begin{array}{l}\text { Irrigation } \\
\text { depth (mm) }\end{array}$ & $\begin{array}{l}\text { Season } \mathrm{ET}_{0} \\
(\mathrm{~mm})\end{array}$ \\
\hline \multirow[t]{2}{*}{2012} & Plot 1 & Rainfed & 0 & 0 & 578 \\
\hline & Plot 2 & Drip & 14 & 128 & \\
\hline \multirow[t]{2}{*}{2013} & Plot 1 & Drip & 15 & 69 & 546 \\
\hline & Plot 2 & & & 58 & \\
\hline \multirow[t]{2}{*}{2014} & Plot 1 & Drip & 15 & 148 & 603 \\
\hline & Plot 2 & & & 141 & \\
\hline
\end{tabular}

performed two days after irrigation to avoid measurement bias as advised by Allen et al. (2011), with a total of 9,11 and 10 measurements days, in 2012, 2013 and 2014, respectively. SWC data were used for calibration and validation of the SIMDualKc model.

During the 2012 season, yield production and quality were evaluated using all plants of three rows per treatment. Differently, at harvests of 2013 and 2014 seasons six plants per treatment were cut off at ground level and the number of bines and cones per plant were accounted. Fresh weight of hop cones harvested in the full experimental area was determined, and then four samples per plant (about $250 \mathrm{gr}$ of hops per sample) were taken and dried at $55 \pm 5^{\circ} \mathrm{C}$ until constant weight was observed. Samples of dry cones were analysed by the 'Sociedad Anónima Española de Fomento de Lúpuloí' (SAEFL), in León, to determine the percentage of alpha and betaacids using the method 7.7 (EBC-European Brewery Convention, 2010). A descriptive analysis of results was applied, for the different years and treatments, in relation to yield and quality parameters.

\subsection{Model calibration and validation}

As previously discussed, model calibration allowed adjusting model parameters to minimize deviations between simulated and observed SWC. SIMDualKc was calibrated with data of Plot 1 in 2013, which was selected because it had higher variability of SWC then the other data sets. The remaining seasons and data from Plot 2 in 2013 were used for validation. Table 3 presents all the initial and calibrated parameter values.

The potential basal crop coefficients obtained are similar to those tabled by Allen et al. (1998); however, $K_{\mathrm{cb} \text { end }}$ values are higher, likely due to the fact that, in this study, harvesting was performed before senescence was much developed. $K_{\mathrm{cb}}$ values reported by Krofta et al. (2013) are much smaller but authors referred the occurrence of water stress during long dry periods within the crop season; thus, those values refer to $K_{\mathrm{cb}}$.act and not to potential $K_{\mathrm{cb}}$. The soil water depletion fraction for no stress $(p)$ values were higher than those proposed by Allen et al. (1998). This fact relates to crop management, to the variety and to the climatic demand, which was not very high in the Galician conditions, particularly at end season, when the calibrated $p_{\text {end }}$ was quite larger than the tabled values. Unfortunately, literature lacks other information on hop $K_{\mathrm{cb}}$ or $K_{\mathrm{c}}$, or relative to the $p$ fraction. The calibrated parameters relative to soil evaporation, deep percolation, groundwater contribution and runoff resulted close to the initial/default ones (Table 3).

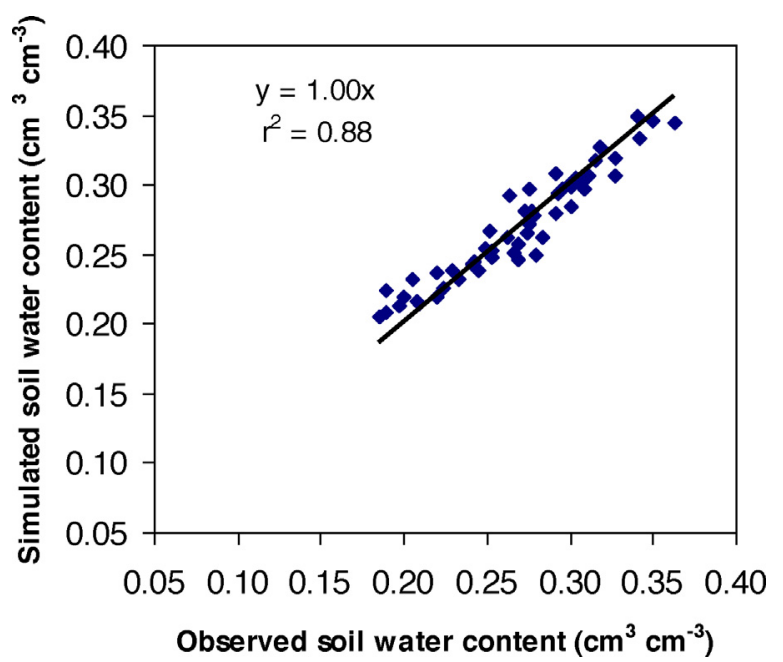

Fig. 2. Observed vs. simulated soil water content relative to all hop experimental data (2012-2014).

The "goodness of fit" indicators relative to model calibration and validation for all crop seasons are shown in Table 4. Results for the regression coefficient $b_{0}$ vary from 0.99 to 1.03 , thus very close to 1.0 , indicating that predicted and observed values were statistically similar for all crop seasons. Values of $r^{2}$ ranged from 0.72 to 0.97 thus indicating that most of the total variance of the observed values was explained by the model. Fig. 2 shows the regression forced to the origin between SWC observations and simulations; it refers to all data sets and confirms the goodness of values obtained for $b_{0}$ and $r^{2}$.

RMSE values are quite low, ranging from 0.012 to $0.015 \mathrm{~cm}^{3} \mathrm{~cm}^{-3}$, thus indicating that errors of estimation were small, representing only $1.2-1.6 \%$ of TAW. These values combined with low RSR ratios (ranging 0.10-0.14), thus indicating low residual errors. AAE values ranged between 0.009 and $0.011 \mathrm{~cm}^{3} \mathrm{~cm}^{-3}$, thus being also quite small. ARE values were also very small, ranging from 3.1 to $5.0 \%$. The PBIAS were very low, indicating a slight over-estimation bias in the calibration plot (PBIAS $=1.5$ ) and a slightly under-estimation bias in plot 2 during the same year. For 2012, PBIAS results show a slight under-estimation bias and for 2014 a very low over-estimation bias. Thus, the model does not show a trend for under or over-estimation bias. The Nash-Sutcliffe 
Table 3

Initial and calibrated model parameters.

\begin{tabular}{|c|c|c|c|}
\hline Parameter & & Initial values $^{\mathrm{c}}$ & Calibrated values \\
\hline \multirow[t]{6}{*}{ Crop } & $K_{\mathrm{cb} \text { Hop ini }}$ & 0.15 & 0.16 \\
\hline & $K_{\mathrm{cb} \text { Hop mid }}$ & 1.00 & 1.00 \\
\hline & $K_{\mathrm{cb} H o p \text { end }}$ & 0.80 & 0.85 \\
\hline & $p_{\text {ini }}$ & 0.50 & 0.60 \\
\hline & $p_{\text {med }}$ & 0.50 & 0.60 \\
\hline & $p_{\text {end }}$ & 0.50 & 0.70 \\
\hline \multirow{3}{*}{ Soil evaporation } & TEW (mm) & 25 & 29 \\
\hline & $\mathrm{REW}(\mathrm{mm})$ & 10 & 9 \\
\hline & $Z_{\mathrm{e}}(\mathrm{m})$ & 0.15 & 0.12 \\
\hline \multirow[t]{2}{*}{ Deep percolation } & $a_{\mathrm{D}}$ & 400 & 380 \\
\hline & $b_{\mathrm{D}}$ & -0.0173 & -0.0173 \\
\hline Runoff & $\mathrm{CN}$ & 75 & 72 \\
\hline Groundwater & $a_{1}$ & 380 & 380 \\
\hline \multirow[t]{7}{*}{ contribution } & $b_{1}$ & -0.17 & -0.17 \\
\hline & $a_{2}$ & 305 & 303 \\
\hline & $b_{2}$ & -0.27 & -0.27 \\
\hline & $a_{3}$ & -1.3 & -1.3 \\
\hline & $b_{3}$ & 6.3 & $6.0^{\mathrm{a}} / 6.6^{\mathrm{b}}$ \\
\hline & $a_{4}$ & 4.2 & $4.0^{\mathrm{a}} / 4.4^{\mathrm{b}}$ \\
\hline & $b_{4}$ & -0.65 & $-1.00^{\mathrm{a}} /-0.85^{\mathrm{b}}$ \\
\hline
\end{tabular}

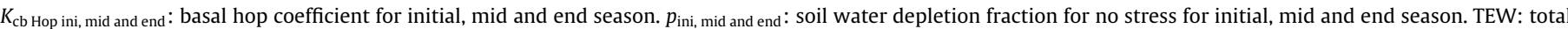

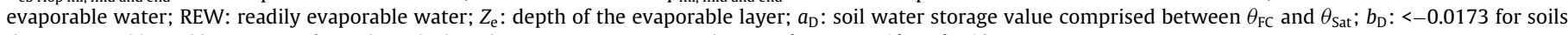
draining quickly and $\mathrm{b}>-0.0173$ for soils with slow drainage; $\mathrm{CN}$ : curve number; $a_{1}: \theta_{\mathrm{FC}} ; a_{2}: 1.1\left(\theta_{\mathrm{FC}}+\theta_{\mathrm{WP}}\right) / 2$.

a Plot 1.

b Plot 2.

c Adapted from Allen et al. (1998, 2007) and Liu et al. (2006).

Table 4

Indicators of "goodness-of-fit" relative to model calibration and validation.

\begin{tabular}{|c|c|c|c|c|c|c|c|c|c|}
\hline & & $b_{0}$ & $r^{2}$ & $\begin{array}{l}\text { RMSE } \\
\left(\mathrm{cm}^{3} \mathrm{~cm}^{-3}\right)\end{array}$ & RSR & $\begin{array}{l}\mathrm{AAE} \\
\left(\mathrm{cm}^{3} \mathrm{~cm}^{-3}\right)\end{array}$ & $\begin{array}{l}\text { ARE } \\
(\%)\end{array}$ & PBIAS (\%) & $\mathrm{EF}$ \\
\hline Calibration & 2013, plot 1 & 0.99 & 0.90 & 0.015 & 0.14 & 0.011 & 4.0 & 1.5 & 0.81 \\
\hline \multirow[t]{3}{*}{ Validation } & 2012 , both plots & 1.01 & 0.73 & 0.012 & 0.10 & 0.010 & 4.4 & -1.9 & 0.84 \\
\hline & 2013, plot 2 & 1.03 & 0.97 & 0.015 & 0.12 & 0.011 & 5.0 & -3.5 & 0.86 \\
\hline & 2014 , both plots & 0.99 & 0.72 & 0.012 & 0.10 & 0.009 & 3.1 & 0.4 & 0.81 \\
\hline
\end{tabular}

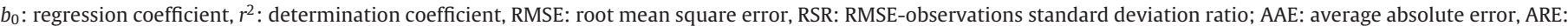
absolute relative error, PBIAS: Percent bias; EF: modelling efficiency.

model efficiency was high for both the calibration $(E F=0.85)$ and validation ( $E F>0.81$ ), which means that the residual variance was much smaller than the measured data variance, thus indicating a good model simulation performance. Overall, the goodness of fit indicators demonstrate the ability of the model to predict the soil water content over a wide range of observed values as well as to predict the terms of the soil water balance, including the actual evapotranspiration.

\subsection{Crop coefficient curves}

The hop potential basal crop coefficient curves $\left(K_{\mathrm{cb} \text { Hop pot }}\right)$ and actual $K_{\mathrm{cb}}$ curves $\left(K_{\mathrm{cb} \text { Hop act }}\right)$, with $K_{\mathrm{cb} \text { Hop act }}=K_{\mathrm{s}} K_{\mathrm{cb} \text { Hop pot }}$, are presented in Fig. 3 together with the evaporation coefficient $\left(K_{\mathrm{e}}\right)$ and the active ground cover basal crop coefficient $\left(K_{\mathrm{cb} \text { gcover }}\right)$. To better follow their dynamics, irrigation and precipitation events are also depicted. Because results for both irrigated plots in 2013 and 2014 were very much similar, only the results for Plot 1 (used for calibration) in 2013 and for Plot 2 in 2014 are presented.

Results show that a slight water stress occurred during the initial crop growth stage in 2012, with the $K_{\mathrm{cb} \text { Hop act }}$ curve laying below that of $K_{\mathrm{cb} H o p}$ pot but for a short period of time only (Fig. 3a and b). Differently, water stress did not occur in 2013 and 2014 in the initial stage. Results for the rain-fed and irrigated plots in 2012 are contrasting. A heavy water stress was observed in the rain-fed plot (Fig. 3a) from the end of the crop development stage until harvest, thus with $K_{\mathrm{cb} \text { Hop act }}$ below the $K_{\mathrm{cb} \text { Hop pot }}$ during the entire midand late-season stages. Contrastingly, the irrigated plot (Fig. 3b) has shown only a mild stress during the mid-season stage. Com- paring the irrigated plots relative to the three crop seasons, it can be observed that only mild water stress occurred: in 2012 during the mid-season, which relate to a severe dry summer where irrigation was insufficient; in 2013, during the late season, due to a dry autumn period; and in 2014, during a very short period of the crop development stage. These results indicate that irrigation was performed with parsimony.

High $K_{\mathrm{e}}$ values were observed during the initial and the crop development stage in response to precipitation that occurred during these periods. This behaviour is similar for all crop seasons analysed, including when comparing the rain-fed with the irrigated plots in 2012 (Fig. 3). Nevertheless, differences between these plots are noticeable in Fig. $3 a$ and b during the mid- and late-season in relation to the occurrence of irrigation events. For all crop seasons, it can be observed (Fig. 3) that the $K_{\mathrm{e}}$ peaks decrease from the crop development stage to the mid-season due to the increased ground cover/shadow by both the hop crop and the active ground cover vegetation or the respective residues when an herbicide is applied. The $K_{\mathrm{cb} \text { gcover }}$ varies among the three crop seasons due to differences in management: in 2012 (Fig. 3a and b) ground cover vegetation was active until end July and $K_{\mathrm{cb} \text { gcover }}$ was relatively high; in 2013 (Fig. 3c) a small $K_{\text {cb gcover }}$ was estimated from midJune to harvest; in 2014 (Fig. 3d), $K_{\text {cb gcover }}$ was quite small but effects of related residues in limiting $K_{\mathrm{e}}$ are observable. For all seasons, a non-negligible and steadily growing $K_{\mathrm{cb} \text { gcover }}$ can be noticed (Fig. 3), that relates to the development of the rapeseed crop in the inter-row.

The curves of the potential $K_{\mathrm{c} \text { Hop }}$, i.e., the sum $K_{\mathrm{cb} \text { Hop }}+\mathrm{K}_{\mathrm{e}}$, resulting from the current study are the following: $K_{\mathrm{c} \text { Hop ini }}=0.69$; 


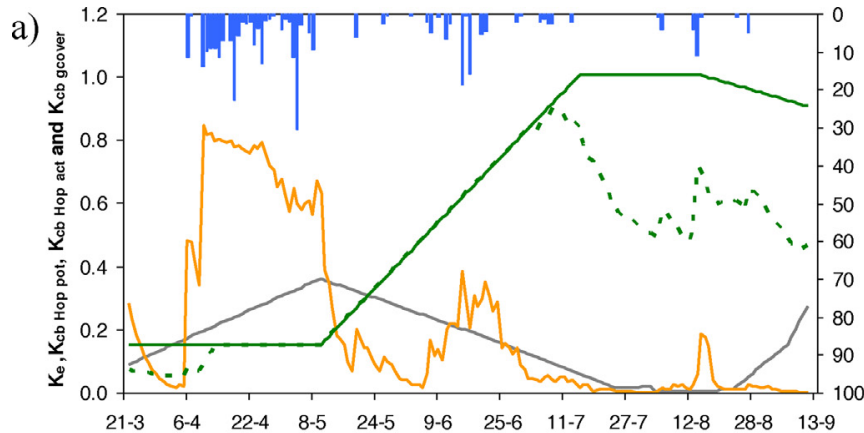

c)

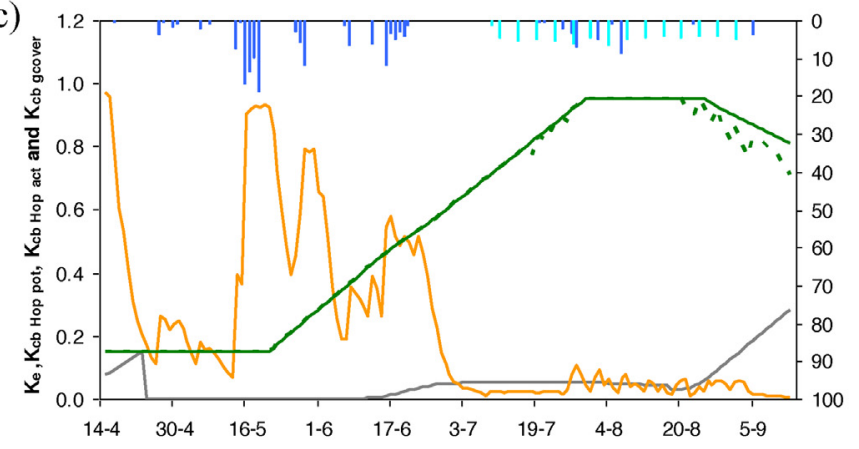

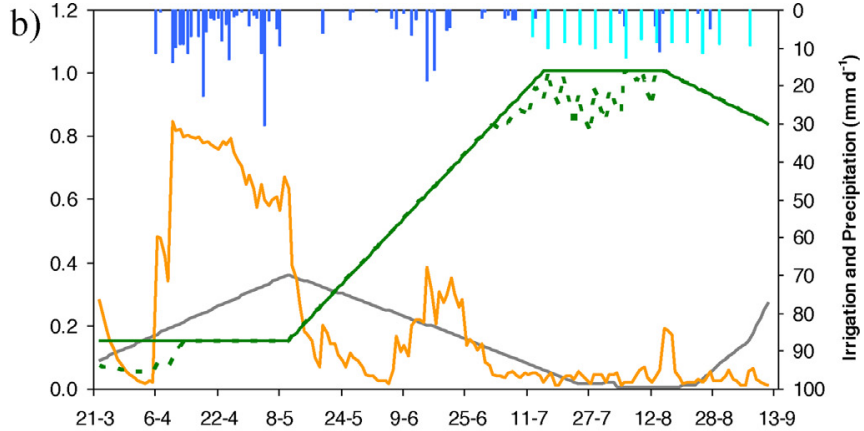

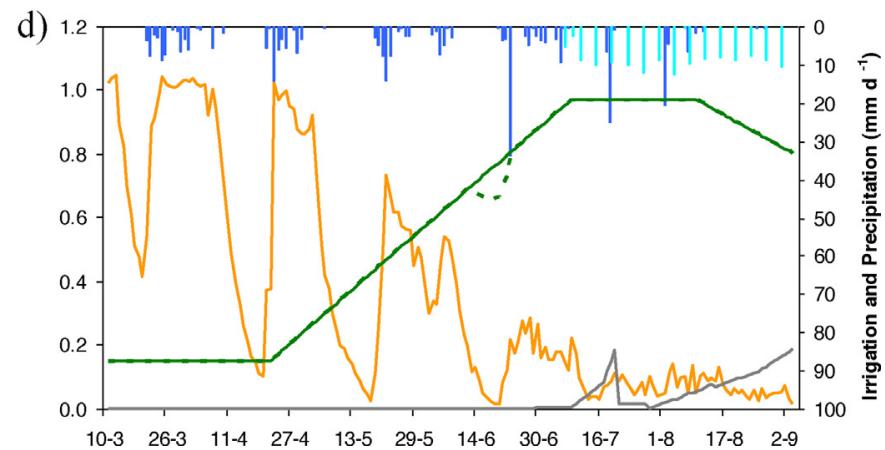

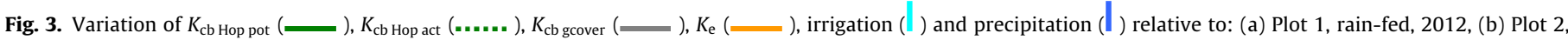
irrigated, 2012, (c) Plot 1, irrigated, 2013, and (d) Plot 2, irrigated, 2014

$K_{\mathrm{c} \text { Hop mid }}=1.02$ and $K_{\mathrm{c} \text { Hop end }}=0.85$. These values are similar to those proposed by Allen et al. (1998) except the tabled $\mathrm{K}_{\mathrm{c} \text { Hop ini }}$ that is much smaller. However those authors recommended that tabled $K_{\text {c ini }}$ values should be replaced by values computed according to the soil wetting amounts, frequency and atmospheric demand. Therefore the proposed value to $K_{\mathrm{c} \text { Hop ini }}$ is appropriate to the climate conditions of the study area. If active ground cover is adopted than the $K_{\mathrm{c}}$ values have to be increased by $0.05-0.20$ in the initial stage, $0.05-0.10$ during mid-season and up to 0.20 at end-season depending upon the inter-row management selected.

The potential basal crop coefficients resulting from this study are the following: $K_{\mathrm{cb} \text { Hop ini }}=0.16 ; K_{\mathrm{cb} \text { Hop mid }}=0.97$ and $K_{\mathrm{cb} \text { Hop end }}=0.83$, which are similar to those tabled by Allen et al. (1998). These $K_{\mathrm{c}}$ and $K_{\mathrm{cb}}$ values should be used with irrigation scheduling models to support irrigation management, hence to support hop growers to manage irrigation with precision and to maximize yield and quality of produces. Examples relative to applications to cotton and maize were reported respectively by Pereira et al. (2009) and Paredes et al. (2014). It is expected that $K_{\mathrm{c} \text { Hop }}$ and $K_{\mathrm{cb} \text { Hop }}$ values proposed herein may also be used as default potential values for other areas, mainly in northern Spain where climate is not very different. Nevertheless, $K_{\mathrm{c} \text { Hop }}$ and $K_{\mathrm{cb} \text { Hop }}$ need to be used with the appropriate information on the actual dates of the phenological stages.

\subsection{ET partitioning and soil water balance components}

The results of partitioning $\mathrm{ET}_{\mathrm{c}}$ act into $E_{\mathrm{s}}, T_{\mathrm{Hop}}$ and $T_{\text {cover }}$ are shown in Fig. 4. Results show that transpiration slightly increases from crop initiation to the mid-season, when the maximum transpiration rate, near $5 \mathrm{~mm} \mathrm{~d}^{-1}$, was attained in the irrigated plots (Fig. $4 \mathrm{~b}-\mathrm{d}$ ). In the rain-fed plot, $T_{\text {Hop }}$ values are similar to those of the irrigated plot in the same year of 2012 but were smaller from the end of the crop development stage until harvesting (cf. Fig. $4 \mathrm{a}$ and $\mathrm{b}$ ). The maximum value for $T_{\text {Hop }}$ of the rain-fed crop was close to $4 \mathrm{~mm} \mathrm{~d}^{-1}$ and was achieved earlier, during the crop development stage, i.e., before water stress affected the crop. This mainly relates with lower water availability which caused crop water stress (Fig. 3a).

Ground cover transpiration varied with the management of the ground cover vegetation (Appendix 1). In $2012 T_{\text {cover }}$ was increasing from crop initiation, at end of the winter, until the competition by the crop reduced its photosynthetic activity when the hop crop developed. A treatment by July also reduced its activity and $T_{\text {cover }}$ became null during late mid-season until rapeseed developed during late season (Fig. 4). Differences between the rain-fed and irrigated plots were only noticeable by the late season when water was fully available for the irrigated plot but insufficient for the rain-fed. Differently, in 2013 the ground cover was active from the crop development stage until harvesting but with a steadily small $T_{\text {cover }}$ while in 2014 ground cover was active from the midseason to harvest, also with small $T_{\text {cover. }}$ By the end of the season and for all years $T_{\text {cover }}$ steadily increased due to sowing rapeseed by the end of mid-season. Thus, $T_{\text {cover }}$ influenced the water availability for the hop crop and therefore decreased $T_{\text {Hop }}$ and $E_{\mathrm{s}}$.

Soil evaporation is high during the initial and crop development stages, when more energy was available at the soil surface for evaporation. $E_{\mathrm{s}}$ is highly influenced by the groundcover vegetation as it can be noticed comparing 2012 (Fig. 4a and b) with the following crop seasons of 2013 and 2014 (Fig. 4c and d): $E_{\mathrm{s}}$ was higher during the referred periods during these years, when ground cover was not active ( $T_{\text {cover }}$ was null) while $E_{\mathrm{s}}$ was smaller in 2012 when an active ground cover was present. This influence is also evidenced in 2013 (Fig. 4c), from the crop development stage until harvesting, where $E_{\mathrm{s}}$ was much smaller than for 2012 and 2014 . In addition, soil evaporation was also affected when vegetation residuals were not removed from the field, thus acting as an organic mulch to reduce $E_{\mathrm{s}}$, This may be observed when interpreting the dynamics of the evaporation coefficient $K_{\mathrm{e}}$ observing together Figs. 3 and 4.

The seasonal soil water balance components of the hop plantation for all three seasons are presented in Table 5 . $\mathrm{ET}_{\mathrm{c}}$ act varied between 398 and $568 \mathrm{~mm}$ while the variation of $T_{\text {Hop }}$ was smaller, from 273 to $371 \mathrm{~mm}$. $T_{\text {Hop }}$ was the main component of $\mathrm{ET}_{\mathrm{c} \text { act }}$ followed by soil evaporation. $T_{\text {Hop }}$ ranged between 65 and $70 \%$ for 

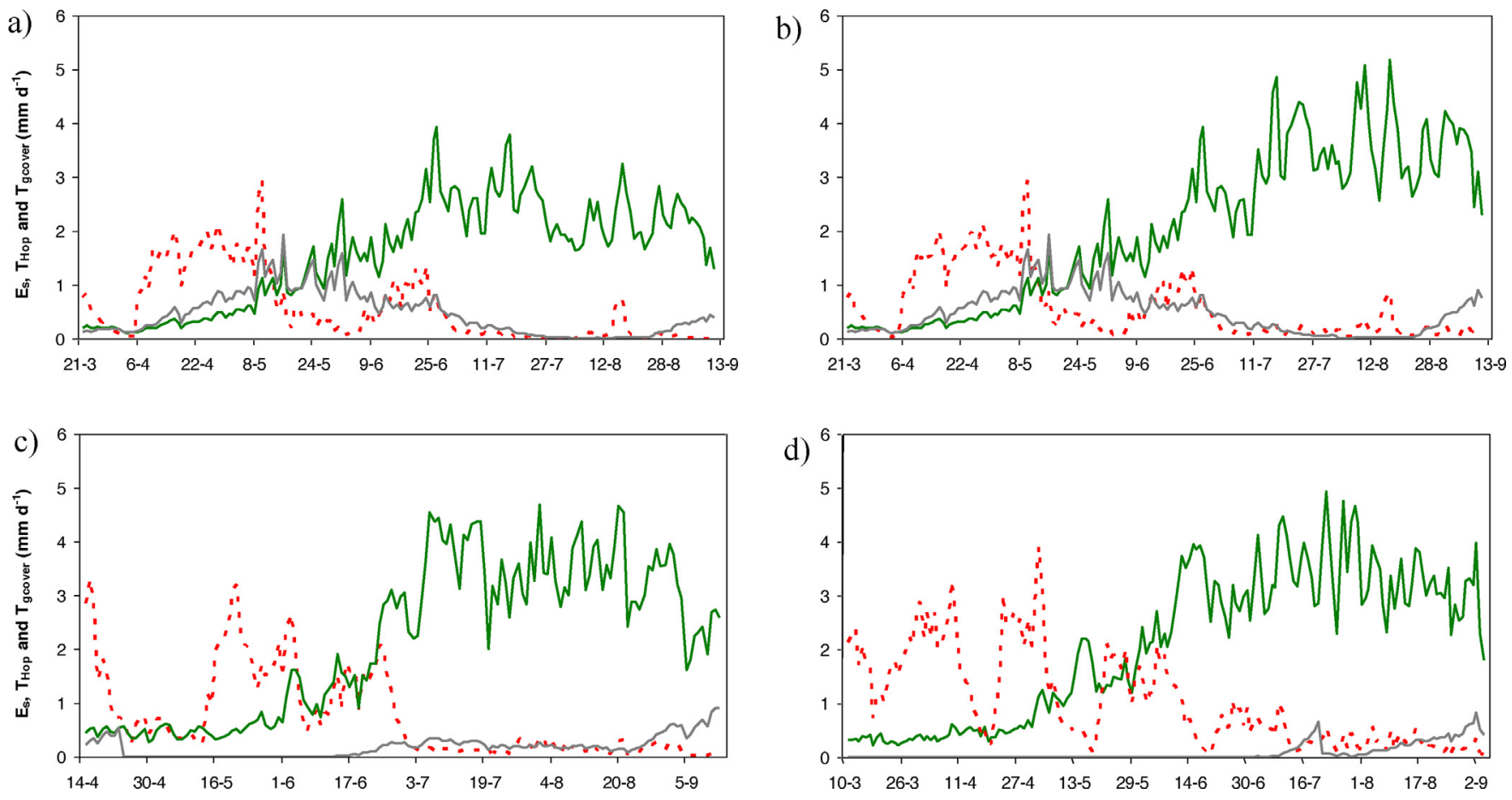

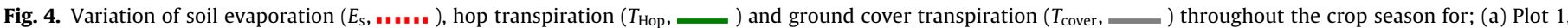
rain-fed, 2012; (b) Plot 2, irrigated, 2012; (c) Plot 1, irrigated, 2013 (calibration) and (d) Plot 2, irrigated, 2014.

Table 5

Partition evapotranspiration and soil water balance components for all experimental plots (2012-2014).

\begin{tabular}{|c|c|c|c|c|c|c|c|c|c|c|}
\hline Treatment & $\begin{array}{l}P \\
(\mathrm{~mm})\end{array}$ & $\begin{array}{l}\mathrm{I} \\
(\mathrm{mm})\end{array}$ & $\begin{array}{l}\mathrm{ET}_{\mathrm{o}} \\
(\mathrm{mm})\end{array}$ & $\begin{array}{l}\mathrm{ET}_{\mathrm{c} \text { act }} \\
(\mathrm{mm})\end{array}$ & $\begin{array}{l}T_{\text {Hop }} \\
(\mathrm{mm})\end{array}$ & $\begin{array}{l}T_{\text {cover }} \\
(\mathrm{mm})\end{array}$ & $\begin{array}{l}E_{\mathrm{s}} \\
(\mathrm{mm})\end{array}$ & $\begin{array}{l}\triangle \mathrm{SWC} \\
(\mathrm{mm})\end{array}$ & $\begin{array}{l}\text { GWC } \\
(\mathrm{mm})\end{array}$ & $\begin{array}{l}\mathrm{RO} \\
(\mathrm{mm})\end{array}$ \\
\hline \multicolumn{11}{|l|}{2012} \\
\hline Plot 1 & 335 & 0 & 578 & 449 & 273 & 79 & 97 & 5 & 125 & 17 \\
\hline Plot 2 & & 128 & & 537 & 352 & 84 & 102 & -20 & 110 & 17 \\
\hline \multicolumn{11}{|l|}{2013} \\
\hline Plot 1 & 172 & 69 & 546 & 461 & 324 & 27 & 110 & 86 & 133 & 3 \\
\hline Plot 2 & & 58 & & 398 & 273 & 23 & 102 & 58 & 109 & 3 \\
\hline \multicolumn{11}{|l|}{2014} \\
\hline Plot 1 & 311 & 148 & 603 & 576 & 375 & 15 & 187 & 13 & 101 & 0 \\
\hline Plot 2 & & 141 & & 568 & 371 & 15 & 182 & 58 & 56 & 0 \\
\hline
\end{tabular}

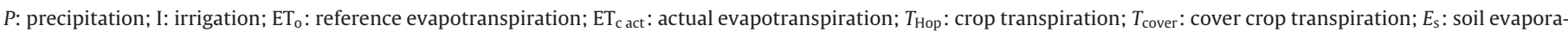
tion; $\triangle$ SWC: variation in stored soil water; GWC: groundwater contribution; RO: runoff.

the irrigated plots, but a lower value was observed in the rain-fed plot due to a high transpiration of the active ground cover in 2012. A much lower $T_{\text {Hop }}$ percentage (29\%) was referred by Urban et al. (2012) likely due to abundant rainfall and bare soil in the interrow. $T_{\text {cover }}$ was high in 2012 but due to different management of the vegetation in the inter-row decreased in the following years becoming negligible in 2014 when it was less than $3 \%$ of $\mathrm{ET}_{\mathrm{c} \text { act }}$. Soil evaporation was an important component of $\mathrm{ET}_{\mathrm{c} \text { act }}$, ranging from 19 to $32 \%$, with low percentages when $T_{\text {cover }}$ was high in 2012 and higher percentage when $T_{\text {cover }}$ was the lowest in 2014 . It can be concluded that ground cover management practices allowed that more energy became available at soil surface for evaporation when $T_{\text {cover }}$ was reduced.

The lowest precipitation was observed in 2013 but due to its good distribution along the crop season and to the capillary rise from a shallow water table, the total irrigation depth was small without greatly affecting crop transpiration but producing only a mild stress. Results show that groundwater contribution (GWC) due to capillary rise plays an important role in supporting $\mathrm{ET}_{\mathrm{c} \text { act }}$ with the ratio $\mathrm{GWC} / \mathrm{ET}_{\mathrm{c}}$ act ranging from $10 \%$ in the Plot 2 in 2014 to $29 \%$ in Plot 1 in the driest season of 2013 . That ratio was also very high (28\%) in the rain-fed plot in 2012. The contribution of the soil water stored in the soil by the end of winter was negligible in 2012 because winter rains were small, and ranged $13-86 \mathrm{~mm}$ in the following years. Higher $\Delta$ SWC was observed in 2013 when rainfall during the crop season was lower and winter rainfall was not low. RO was negligible, representing 5 and $1 \%$ of the precipitation in 2012 and 2013, respectively; the higher value observed in 2012 was due to a heavy rain of approximately $40 \mathrm{~mm}$ that occurred when soil water storage was high. Deep percolation was not observed/simulated likely because heavy rains did not occur during the study seasons and surface drip irrigation management was appropriate.

\subsection{Impacts of hop transpiration on hops yield and quality}

Mean of hop cone yield were calculated for all treatments (Table 6). In 2012, yield obtained in the rain-fed plot 1 was $37 \%$ lower than in the irrigated plot 2. In 2013 and 2014 all plots were irrigated and results of plot 1 and 2 were computed together, so the trend observed in 2012 could not be followed. To assess the impacts of water use on hop cone yield a linear regression between yield 
Table 6

Yield and quality parameters of hops cv. 'Nugget'.

\begin{tabular}{llll}
\hline Treatment & $\begin{array}{l}\text { Dry matter hops } \\
\left(\mathrm{kg} \mathrm{ha}^{-1}\right)\end{array}$ & $\begin{array}{l}\text { Alpha-acids } \\
(\%)\end{array}$ & $\begin{array}{l}\text { Beta-acids } \\
(\%)\end{array}$ \\
\hline 2012 & & & \\
Plot 1 & 932.7 & 13.06 & 4.11 \\
Plot 2 & 1486.0 & 12.66 & 4.06 \\
2013 & & 12.83 & 4.05 \\
Plot 1 & 869.3 & & \\
Plot 2 & & & 4.60 \\
2014 & & 12.70 & \\
Plot 1 & 1639.1 & & \\
Plot 2 & & &
\end{tabular}

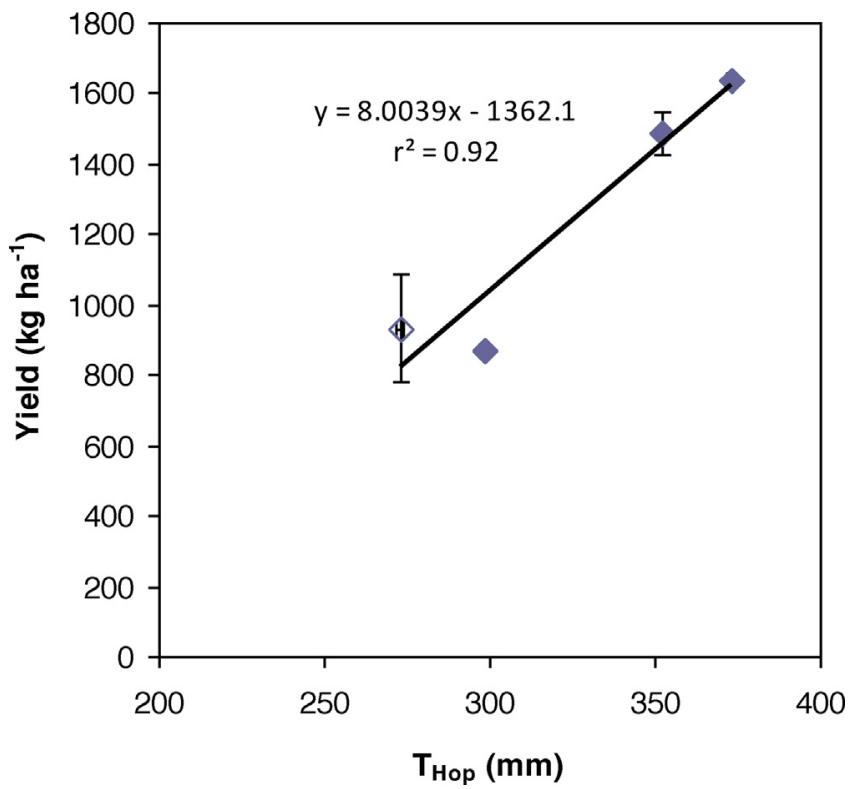

Fig. 5. Linear regression between yield (dry matter hops) and hop transpiration $\left(T_{\text {Hop }}\right)$. Filled points represented irrigated experiment; empty point represented rain-fed data. Error bars represented standard deviation.

and hop transpiration was applied. It resulted a positive regression coefficient and a high coefficient of determination $r^{2}=0.92$ (Fig. 5). These results show that transpiration favours hops yield. Svoboda et al. (2008) and Delahunty et al. (2011) reported an increase about yield due to irrigation. Mozny et al. (2009) referred that yields increased under rainfed conditions when summer precipitation was higher, and Nakawuka (2013) referred positive trends relative to evapotranspiration. However, no relations with transpiration are reported in the literature.

Average observed values of the alpha and beta-acids content are given in Table 6. Alpha-acids observed in the current study were similar to average values reported by Olmedo et al. (2009) at the same location. Linear regressions relating $T_{\text {Hop }}$ and alphaacids, beta-acids and the ratio between alpha and beta-acids have shown regression coefficients not significantly different from zero. This behaviour could be expected knowing that the acids contents relate mostly with the cultivar unless that a high differentiation of temperature and water availability could have been imposed, what was not the case. Nakawuka (2013) reported that no significant differences were found relative to content of alpha-acids between irrigation treatments. A variation of alpha-acids could be expected in relation to the temperature pattern at the end of the cycle, when alpha-acids synthesis is more intense; however, temperature by then was not very different for the three years of study and irrigation applied until the end of the season was enough to do not produce stress by then. Wang et al. (2008) described that accumulation of alpha-acids as most intensive in third and fourth week after hop flowering. Srečec et al. (2008) found a significant decrease of alpha-acids when the climatic demand for water at the flowering and cone formation stage was very high and rainfall was insufficient. Differently, Benítez et al. (1998) reported a non-response to climatic data. The reported differential effects of temperature and water availability might be related to the time points of the different phenological stages as the described effects of temperature (negative effect) and water supply (positive effect) are most relevant during flowering, cone formation and early ripening, i.e., before the strongest accumulation of alpha-acids. In general, results on trends of alpha-acids showed differences in relation with cultivar, location and climate conditions, mainly from vegetative stages until early ripening stages (Srečec et al., 2008, 2013; Pavlovic et al., 2012, 2013; Potop, 2014).

Several metabolic pathways are involved in the biosynthesis of alpha and beta-acids (Zanoli and Zavatti, 2008). It is often considered that, during the biosynthesis of the bitter substances in cones, first a surplus of the beta-acids compared to the alpha-acids may occur (Goese et al., 1999). Subsequently, beta-acids convert into alpha-acids, or are degraded by oxidation, and the ratio alpha-beta acids then increases. If increase of transpiration does not promote the synthesis of alpha-acids, it may happen that beta-acids accumulate and then a positive correlation appears. However, excluding the rain-fed treatment, since no water or heat stress occurred, a balance between alpha and beta-acids was observed that resulted in a stable concentration of bitter acids in the three years of study since that concentration is mainly dependent on the cultivar, in absence of extreme climate conditions (Čeh et al., 2007). Nakawuka (2013) also reported that no significant differences were found relative to content of beta-acids.

\section{Conclusions}

The SIMDualKc model performed well in determining hop transpiration and the soil water balance components of $H$. lupulus L. cv. 'Nugget' cropped in Galicia, namely soil evaporation, groundwater contribution, deep percolation and runoff. $T_{\text {Hop }}$ represent $92 \%$ of $\mathrm{ET}_{\mathrm{c} \text { act }}$ during the mid-season, and $E_{\mathrm{s}}$ was $69 \%$ of $\mathrm{ET}_{\mathrm{c} \text { act }}$ during the initial stage. Calibrated parameters, particularly basal crop coefficients, depletion fraction for no stress and soil evaporation parameters may well be used as default parameters for operational applications of the model when to be used to support irrigation management or for planning purposes.

A linear regression between $T_{\text {Hop }}$ and dry yield cone $\left(r^{2}=0.92\right)$ has shown that yield increases when crop and irrigation management favour crop transpiration. Differently, the linear regressions between $T_{\text {Hop }}$ and the concentrations of alpha-acids and beta-acids had regression coefficients not significantly different from zero. This result means that the applied irrigation management did not influence the synthesis of the bitter acids, which is cultivar dependent but could be modified if stress had occurred. Thus, it could be concluded that irrigation management applied was appropriate in terms of the quality of the hop cones produced. Nevertheless, it is desirable to develop further research using different treatments which could induce different responses of the crop in terms of quality and that could confirm the hop yield responses to water.

\section{Acknowledgements}

This research was funded by the enterprise 'Hijos de Rivera Inversiones Corporativas, S.L.' (Estrella de Galicia beer) (CN-12-045), European Agricultural Fund for Rural Development (EAFRD), No. 2012/34, through Consellería do Medio Rural e do Mar-Xunta de Galicia. First author thanks to 'LEAF - Landscape, Environment, Agriculture and Food (ISA-Univ. Lisbon) for the invitation to develop a stay research. 
Appendix 1.

Fraction, density and height of the active ground cover, before and after each ground cover management operation for all seasons.

\begin{tabular}{|c|c|c|c|c|c|c|c|}
\hline \multirow{3}{*}{$\begin{array}{l}\text { Date } \\
2012\end{array}$} & \multirow[t]{3}{*}{ Location } & \multicolumn{2}{|l|}{$f_{\text {gcover }}$} & \multicolumn{2}{|l|}{ Density } & \multicolumn{2}{|l|}{$h_{\text {gcover }}$} \\
\hline & & \multirow[t]{2}{*}{ Before } & \multirow[t]{2}{*}{ After } & \multirow[t]{2}{*}{ Before } & \multirow[t]{2}{*}{ After } & \multirow[t]{2}{*}{ Before } & \multirow[t]{2}{*}{ After } \\
\hline & & & & & & & \\
\hline Initial Conditions & Row & 40 & 40 & 15 & 15 & 0.05 & 0.05 \\
\hline (22-March) & Inter-row & 37 & 37 & 25 & 25 & 0.05 & 0.05 \\
\hline 10-May & Row & 80 & 80 & 30 & 30 & 0.10 & 0.10 \\
\hline 10-May & Inter-row & 75 & 75 & 50 & 50 & 0.10 & 0.10 \\
\hline 27-June & Row & 65 & 65 & 50 & 50 & 0.20 & 0.20 \\
\hline 24-July & Inter-row-sowing & 0 & 0 & 0 & 0 & 0.00 & 0.00 \\
\hline 26-July & Row & 65 & 65 & 30 & 30 & 0.25 & 0.25 \\
\hline 03-August & Row-herbicide* & 65 & 0 & 30 & 0 & 0.30 & 0.00 \\
\hline 23-August & Inter-row & 85 & 85 & 1 & 1 & 0.01 & 0.01 \\
\hline 02-September & Inter-row & 85 & 85 & 15 & 15 & 0.03 & 0.03 \\
\hline 06-September & Inter-row & 85 & 85 & 20 & 20 & 0.05 & 0.05 \\
\hline Final conditions & Row & 0 & 0 & 0 & 0 & 0.00 & 0.00 \\
\hline (11-September) & Inter-row & 85 & 85 & 35 & 35 & 0.10 & 0.10 \\
\hline \multicolumn{8}{|l|}{2013} \\
\hline Initial conditions & Row & 0 & 0 & 0 & 0 & 0.00 & 0.00 \\
\hline (15-April) & Inter-row & 30 & 30 & 30 & 30 & 0.02 & 0.02 \\
\hline 24-April & Inter-row & 30 & 0 & 60 & 0 & 0.05 & 0.00 \\
\hline 31-May & Row & 0 & 10 & 0 & 10 & 0.00 & 0.01 \\
\hline 07-June & Row & 10 & 10 & 10 & 10 & 0.02 & 0.02 \\
\hline 14-June & Row & 20 & 20 & 20 & 20 & 0.05 & 0.05 \\
\hline 28-June & Row & 85 & 85 & 70 & 70 & 0.25 & 0.25 \\
\hline 31-July & Inter-row-sowing & 0 & 0 & 0 & 0 & 0.00 & 0.00 \\
\hline 31-July & Row & 85 & 85 & 70 & 70 & 0.40 & 0.40 \\
\hline 18-August & Row-herbicide* & 40 & 0 & 35 & 0 & 0.40 & 0.00 \\
\hline 22-August & Inter-row & 85 & 85 & 5 & 5 & 0.01 & 0.01 \\
\hline 27-August & Inter-row & 85 & 85 & 10 & 10 & 0.02 & 0.02 \\
\hline Final conditions & Row & 0 & 0 & 0 & 0 & 0.00 & 0.00 \\
\hline (13-September) & Inter-row & 85 & 85 & 35 & 35 & 0.15 & 0.15 \\
\hline \multicolumn{8}{|l|}{2014} \\
\hline Initial conditions & Row & 0 & 0 & 0 & 0 & 0.00 & 0.00 \\
\hline (11-March) & Inter-row & 0 & 0 & 0 & 0 & 0.00 & 0.00 \\
\hline 10-June & Row & 0 & 10 & 0 & 10 & 0.00 & 0.00 \\
\hline 17-June & Row & 15 & 15 & 15 & 15 & 0.02 & 0.02 \\
\hline 26-June & Row & 15 & 15 & 20 & 20 & 0.02 & 0.02 \\
\hline 02-July & Row & 20 & 20 & 20 & 20 & 0.03 & 0.03 \\
\hline 09-July & Row & 33 & 33 & 20 & 20 & 0.05 & 0.05 \\
\hline 09-July & Inter-row & 0 & 0 & 0 & 0 & 0.00 & 0.00 \\
\hline 17-July & Inter-row & 40 & 40 & 20 & 20 & 0.05 & 0.05 \\
\hline 17-July & Row & 33 & 33 & 40 & 40 & 0.10 & 0.10 \\
\hline 21-July & Row & 40 & 40 & 50 & 50 & 0.10 & 0.10 \\
\hline 21-July & Inter-row - ploughed & 50 & 0 & 40 & 0 & 0.15 & 0.00 \\
\hline 29-July & Row-herbicide* & 40 & 0 & 50 & 0 & 0.15 & 0.00 \\
\hline 29-July & Inter-row-sowing & 0 & 0 & 0 & 0 & 0.00 & 0.00 \\
\hline 15-August & Row* & 40 & 0 & 30 & 0 & 0.15 & 0.00 \\
\hline 26-August & Inter-row & 85 & 85 & 15 & 15 & 0.05 & 0.05 \\
\hline Final conditions & Row & 0 & 0 & 0 & 0 & 0.00 & 0.00 \\
\hline (04-September) & Inter-row & 85 & 85 & 25 & 25 & 0.10 & 0.10 \\
\hline
\end{tabular}

$f_{\text {gcover }}$ : fraction of the green active ground cover; $h_{\text {gcover }}$ : height of the green active ground cover *Turns to mulch.

\section{Appendix A. Supplementary data}

Supplementary data associated with this article can be found, in the online version, at http://dx.doi.org/10.1016/j.indcrop.2015.08. 042.

\section{References}

Abram, V., Čeh, B., Vidmar, M., Hercezi, M., Lazić, N., Bucik, V., Mozina, S.S., Kosirb, I.J., Kaca, M., Demsar, L., Ulrih, N.P., 2015. A comparison of antioxidant and antimicrobial activity between hop leaves and hop cones. Ind. Crops Prod. 64, 124-134.

Allen, R.G., Pereira, L.S., 2009. Estimating crop coefficients from fraction of ground cover and height. Irrig. Sci. 28, 17-34.
Allen, R.G., Pereira, L.S., Raes, D., Smith, M., 1998. Crop Evapotranspiration. Guidelines for Computing Crop Water Requirements. FAO Irrigation and Drainage Paper 56, FAO, Rome, Italy, pp. 300.

Allen, R.G., Pereira, L.S., Smith, M., Raes, D., Wright, J.L., 2005. FAO-56 dual crop coefficient method for estimating evaporation from soil and application extensions. J. Irrig. Drain. Eng. 131, 2-13.

Allen, R.G., Wright, J.L., Pruitt, W.O., Pereira, L.S., 2007. Water requirements. In: Hoffman, G.J., Evans, R.G., Jensen, M.E., Martin, D.L., Elliot, R.L. (Eds.), Design and Operation of Farm Irrigation Systems. , 2nd edn. ASABE Monograph, St. Joseph, MI, pp. 208-288.

Allen, R.G., Pereira, L.S., Howell, T.A., Jensen, M.E., 2011. Evapotranspiration information reporting: I. Factors governing measurement accuracy. Agric. Water Manage. 98 (6), 899-920.

Bárek, V., Halaj, P., Igaz, D., 2009. The influence of climate change on water demands for irrigation of special plants and vegetables in Slovakia. In: Strelcová, K. (Ed.), Bioclimatology and Natural Hazards. Springer, Netherlands, pp. 271-282. 
Bavec, F., Brežnik, B.C., Brežnik, M., 2003. Hop yield evaluation depending on experimental plot area under different nitrogen management. Plant Soil Environ. 49 (4), 163-167.

Benítez, J.L., Magadán, J.A., G del Valle, M.D., Santamarta, I., 1998. Estudio de la influencia de las condiciones meteorológicas en la producción de alfa ácidos en la provincia de León. Cerveza y Malta XXXV 140 (4), 20-22.

Briggs, D.E., Boulton, C.A., Brookes, P.A., Stevens, R., 2000. Brewing Science and Practice. Woodhead Publishing Limited, Cambridge.

Cameira, M.R., Fernando, R.M., Ahuja, L., Pereira, L.S., 2005. Simulating the fate of water in field soil-crop environment. J. Hydrol. 315, 1-24.

Cammalleri, C., Rallo, G., Agnese, C., Ciraolo, G., Minacapilli, M., Provenzano, G. 2013. Combined use of eddy covariance and sap flow techniques for partition of ET fluxes and water stress assessment in an irrigated olive orchard. Agric. Water Manage. 120, 89-97.

Cancela, J.J., Fandiño, M., Rey, B., Martínez, E., 2015. Automatic irrigation system based on dual crop coefficient, soil and plant water status for Vitis vinifera (cv Godello and cv Mencía). Agric. Water Manage. 151, 52-63.

Čeh, B., Kač, M., Košir, J.I., Abram, V., 2007. Relationships between xanthohumol and polyphenol content in hop leaves and hop cones with regard to water supply and cultivar. Int. J. Mol. Sci. 8, 989-1000.

Centinari, M., Poni, S., Intrigliolo, D.S., Dragoni, D., Lakso, A.N., 2012. Cover crop evapotranspiration in a northeastern US Concord (Vitis labruscana) vineyard. Aust. J. Grape Wine Res. 18, 73-79.

Delahunty, K., Johnston, J., Westfield, M.E., 2011. An Experiment on the Effectiveness of Irrigation and Cover Cropping to Produce Sustainable Hops in Maine. USDA Northeast SARE Final Report: FNE11-711.

Ding, R., Kang, S., Zhang, Y., Hao, X., Tong, L., Du, T., 2013. Partitioning evapotranspiration into soil evaporation and transpiration using a modified dual crop coefficient model in irrigated maize field with ground-mulching. Agric. Water Manage. 127, 85-96.

EBC-European Brewery Convention, 2010. Analytica-EBC. Section 7Hops Method $7.7 \alpha$ - and $\beta$-acids in Hop and Hop Products by HPLC. EBC Methods of Analysis. Fachverlag Hans Carl, Nürnberg, Germany.

Engelhard, B., 2004. The impact of weather conditions on the behaviour of powdery mildew in infecting hop (Humulus). In: I International Humulus Symposium. Acta Hortic. 668, 111-116

Fandiño, M., Cancela, J.J., Rey, B.J., Martínez, E.M., Rosa, R.G., Pereira, L.S., 2012. Using the dual-kc approach to model evapotranspiration of albariño vineyards (Northwest Spain) with consideration of active ground cover. Agric. Water Manage 112, 75-87.

Forkutsa, I., Sommer, R., Shirokova, Y.I., Lamers, J.P.A., Kienzler, K., Tischbein, B., Martius, C., Vlek, P.L.G., 2009. Modeling irrigated cotton with shallow groundwater in the Aral Sea Basin of Uzbekistan: I. Water dynamics. Irrig. Sci. 27, 331-346.

Gloser, V., Baláž, M., Jupa, R., Korovetska, H., Svoboda, P., 2013. The response of Humulus lupulus to drought: the contribution of structural and functional plant traits. In: III International Humulus Symposium. Acta Hortic. 1010, 149-154.

Goese, M., Kammhuber, K., Bacher, A., Zenk, M.H., Eisenreich, W., 1999. Biosynthesis of bitter acids in hops. Eur. J. Biochem. 263, 447-454.

González, M.G., Ramos, T.B., Carlesso, R., Paredes, P., Petry, M.T., Martins, J.D., Aires, N.P., Pereira, L.S., 2015. Modelling soil water dynamics of full and deficit drip irrigated maize cultivated under a rain shelter. Biosyst. Eng. 132, 1-18.

Grünberger, O., Michelot, J.L., Bouchaou, L., Macaigne, P., Hsissou, Y., Hammecker, C., 2011. Capillary rise quantifications based on in-situ artificial deuterium peak displacement and laboratory soil characterization. Hydrol. Earth Syst. Sci. 15, 1629-1639.

Hniličková, H., Hnilička, F., Svoboda, P., Kořen, J., 2009. The impact of water deficit on selected physiological characteristics of juvenile hop plants (Humulus lupulus L.). Cereal Res. Commun. 37, 301-304.

Keukeleire, J., de Janssens, I., Heyerick, A., Ghekiere, G., Cambie, J., Roldan-Ruiz, I., Van Bockstaele, E., De Keukeleire, D., 2007. Relevance of organic farming and effect of climatological conditions on the formation of alpha-acids, beta-acids, desmethylxanthohumol, and xanthohumol in hop (Humulus lupulus L.). J. Agric. Food Chem. 55 (1), 61-66.

Kool, D., Agam, N., Lazarovitch, N., Heitman, J.L., Sauer, T.J., Ben-Gal, A., 2014. A review of approaches for evapotranspiration partitioning. Agric. For. Meteorol. $184,56-70$.

Kořen, J., 2007. Influence of plantation row spacing on quality and yield of hops. Plant Soil Environ. 53 (6), 276-282.

Kottek, M., Grieser, J., Beck, C., Rudolf, B., Rubel, F., 2006. World map of the Köppen-Geiger climate classification updated. Meteorol. Z. 15 (3), 259-263.

Krofta, K., Kučera, J., Urban, J., 2013. Transpiration-an important contribution to overall water balance of the hop plantation. In: III International Humulus Symposium. Acta Hortic. 1010, 183-190.

Kučera, J., Krofta, K., 2009. Mathematical model for prediction of yield and alpha acid contents from meteorological data for saaz aroma variety. Acta Hortic. $848,131-139$.

Liu, Y., Pereira, L.S., Fernando, R.M., 2006. Fluxes through the bottom boundary of the root zone in silty soils: parametric approaches to estimate groundwater contribution and percolation. Agric. Water Manage. 84, 27-40.

Luo, Y., Sophocleous, M., 2010. Seasonal groundwater contribution to crop-water use assessed with lysimeter observations and model simulations. J. Hydrol. 389, 325-335.

Luo, Y., He, C., Sophocleous, M., Yin, Z., Ren, H., Zhu, O., 2008. Assessment of crop growth and soil water modules in SWAT2000 using extensive field experiment data in an irrigation district of the Yellow River Basin. J. Hydrol. 352, 139-156.
Ma, Y., Feng, S., Song, X., 2013. A root zone model for estimating soil water balance and crop yield responses to deficit irrigation in the North China Plain. Agric. Water Manage. 127, 13-24.

Martins, J.D., Rodrigues, G.C., Paredes, P., Carlesso, R., Oliveira, Z.B., Knies, A.E., Petry, M.T., Pereira, L.S., 2013. Dual crop coefficients for maize in Southern Brazil: model testing for sprinkler and drip irrigation and mulched soil. Biosyst. Eng. 115 (3), 291-310.

Moir, M., 2000. Hops-a millenium review. J. Am. Soc. Brew. Chem. 58 (4), 131-146.

Moriasi, D.N., Arnold, J.G., Van Liew, M.W., Bingner, R.L., Harmel, R.D., Veith, T.L., 2007. Model evaluation guidelines for systematic quantification of accuracy in watershed simulations. T. ASABE 50, 885-900.

Mozny, M., Tolasz, R., Nekovar, J., Sparks, T., Trnka, M., Zalud, Z., 2009. The impact of climate change on the yield and quality of Saaz hops in the Czech Republic. Agric. Forest Meteorol. 149, 913-919.

Nakawuka, P., 2013. Effect of Deficit Irrigation on Yield, Quality and Grower Returns of Native Spearmint and Hops in Washington State. Doctoral Dissertation. Washington State University.

Nash, J.E., Sutcliffe, J.V., 1970. River flow forecasting through conceptual models: part 1. A discussion of principles. J. Hydrol. 10 (3), 282-290.

Olmedo, J.L., 2011. Recuperación del cultivo del Lúpulo en Galicia. Cerveza y Malta XLVIII 192 (4), 51-58

Olmedo, J.L., Valladares, J., Fernández, J., Piñeiro, J., 2009. Recovering hop cultivation in Galicia (NW Spain). In: In: International Hop Growers‘ Convention (I.H.G.C.) Proceedings of the Scientific Commission, León, Spain, p. p 117.

Paço, T.A., Ferreira, M.I., Rosa, R.D., Paredes, P., Rodrigues, G.C., Conceição, N., Pacheco, C.A., Pereira, L.S., 2012. The dual crop coefficient approach using a density factor to simulate the evapotranspiration of a peach orchard: SIMDualKc model versus eddy covariance measurements. Irrig. Sci. 30 (2), 115-126.

Paço, T.A., Pôças, I., Cunha, M., Silvestre, J.C., Santos, F.L., Paredes, P., Pereira, L.S., 2014. Evapotranspiration and crop coefficients for a super intensive olive orchard. An application of SIMDualKc and METRIC models using ground and satellite observations. J. Hydrol. 519, 2067-2080.

Paredes, P., Rodrigues, G.C., Alves, I., Pereira, L.S., 2014. Partitioning evapotranspiration, yield prediction and economic returns of maize under various irrigation management strategies. Agric. Water Manage. 135, 27-39.

Pavlovic, V., Pavlovic, M., Cerenak, A., Kosir, I.J., Ceh, B., Rozman, C., Turk, J., Pazek, K., Krofta, K., Gregoric, G., 2012. Environment and weather influence on quality and market value of hops. Plant Soil Environ. 58 (4), 155-160.

Pavlovic, M., Pavlovic, V., Rozman, C., Udovc, A., Stajnko, D., Wang, D., Gavric, M., Srecec, S., 2013. Market value assessment of hops by modeling of weather attributes. Plant Soil Environ. 59 (6), 267-272.

Pereira, L.S., Paredes, P., Cholpankulov, E.D., Inchenkova, O.P., Teodoro, P.R., Horst, M.G., 2009. Irrigation scheduling strategies for cotton to cope with water scarcity in the Fergana Valley, Central Asia. Agric. Water Manage. 96, 723-735.

Pereira, L.S., Paredes, P., Rodrigues, G.C., Neves, M., 2015. Modeling malt barley water use and evapotranspiration partitioning in two contrasting rainfall years. Assessing AquaCrop and SIMDualKc models. Agric. Water Manage. 159, 239-254.

Potop, V., 2014. The impact of dry and wet events on the quality and yield of Saaz hops in the Czech hop growing regions. In: Rožnovský, J., Litschmann, T., (eds): Mendel a bioklimatologie. ISBN 978-80-210-6983-1.

Raes, D., Geerts, S., Kipkorir, E., Wellens, J., Sahli, A., 2006. Simulation of yield decline as a result of water stress with a robust soil water balance model Agric. Water Manage. 81 (3), 335-357.

Ramos, T.B., Šimůnek, J., Gonçalves, M.C., Martins, J.C., Prazeres, A., Pereira, L.S. 2012. Two-dimensional modeling of water and nitrogen fate from sweet sorghum irrigated with fresh and blended saline waters. Agric. Water Manage. 111, 87-104.

Ritchie, J.T., 1972. Model for predicting evaporation from a row crop with incomplete cover. Water Resour. Res. 8, 1204-1213.

Robinson, D.A., Jones, S.B., Wraith, J.M., Or, D., Friedman, S.P., 2003. A review of advances in dielectric and electrical conductivity measurement in soils using time domain reflectometry. Vadose Zone J. 2, 444-475.

Rosa, R.D., Paredes, P., Rodrigues, G.C., Alves, I., Fernando, R.M., Pereira, L.S., Allen, R.G., 2012a. Implementing the dual crop coefficient approach in interactive software. 1. Background and computational strategy. Agric. Water Manage. $103,8-24$.

Rosa, R.D., Paredes, P., Rodrigues, G.C., Fernando, R.M., Alves, I., Pereira, L.S., Allen, R.G., 2012b. Implementing the dual crop coefficient approach in interactive software. 2. Model testing. Agric. Water Manage. 103, 62-77.

Rossbauer, G., Buhr, L., Hack, H., Hauptmann, S., Klose, R., Meier, U., Stauss, R., Weber, E., 1995. Phänologische entwicklungsstadien von Kultur-Hopfen (Humulus lupulus L.). Nachrichtenbl. Deut. Pflanzenschutzd. 47 (10), 249-253

Rothfuss, Y., Biron, P., Braud, I., Canale, L., Durand, J.-L., Gaudet, J.-P., Richard, P., Vauclin, M., Bariac, T., 2010. Partitioning evapotranspiration fluxes into soil evaporation and plant transpiration using water stable isotopes under controlled conditions. Hydrol. Process. 24, 3177-3194.

Schönberger, C., Kostelecky, T., 2011. 125th anniversary review: the role of hops in brewing. J. Inst. Brew. 117 (3), 259-267.

Souto, F.J., Dafonte, J., Escariz, M., 2008. Design and air-water calibration of a waveguide connector for TDR measurements of soil electric permittivity in stony soils. Biosyst. Eng. 101 (4), 463-471. 
Srečec, S., Kvaternjak, I., Kaučić, D., Marić, V., 2004. Dynamics of hop growth and accumulation of $\alpha$-acids in normal and extreme climatic conditions. Agric. Conspec. Sci. 69 (2-3), 59-62.

Srečec, S., Kvaternjak, I., Kaučic, D., Špoljar, A., Erhatić, R., 2008. Influence of climatic conditions on accumulation of alpha-acids in hop cones. Agric. Conspec. Sci. 73, 161-166.

Srečec, S., Čeh, B., Ciler, T.S., Ferlež, A.R., 2013. Empiric mathematical model for predicting the content of alpha-acids in hop ( Humulus lupulus L.) cv. Aurora. SpringerPlus, 2, 59.

Steenackers, B., De Cooman, L., De Vos, D., 2015. Chemical transformations of characteristic hop secondary metabolites in relation to beer properties and the brewing process: a review. Food Chem. 172, 742-756.

Sutanto, S.J., Wenninger, J., Coenders-Gerrits, A.M.J., Uhlenbrook, S., 2012. Partitioning of evaporation into transpiration, soil evaporation and interception: a comparison between isotope measurements and a HYDRUS-1D model. Hydrol. Earth Syst. Sci. 16, 2605-2616.

Svoboda, P., Hniličková, H., Hnilička, F., 2008. Changes in yield and quality of hop depending on the irrigation. Cereal Res. Commun. 36, 891-894.

Topp, G.C., Davis, J.L., Annan, A.P., 1980. Electromagnetic determination of soil water content: measurement in coaxial transmission lines. Water Resour. Res. $16,574-582$.

Urban, J., Krofta, K., Kučera, J., 2012. Calibration of stem heat balance sensors upon a study of water balance of the hop plantation. In: VIII International Symposium on Sap Flow. Acta Hortic. 951, 79-86.

USDA-SCS, 1972, National Engineering Handbook, Section 4, Washington, D.C.

Verzele, M., 1986. 100 years of hop chemistry and its relevance to brewing. J. Inst. Brew. 92, 33-48.

Wample, R.L., Farrar, S.L., 1983. Yield and quality of furrow and trickle irrigated hop (Humulus lupulus L.) in Washington state. Agric. Water Manage. 7. 457-470.
Wang, G., Tian, L., Aziz, N., Broun, P., Dai, X., He, J., King, A., Zhao, P.X., Dixon, R.A., 2008. Terpene biosynthesis in glandular trichomes of hop. Plant Physiol. 148, $1254-1266$

Wang, X., Williams, J.R., Gassman, P.W., Baffaut, C., Izaurralde, R.C., Jeong, J., Kiniry, J.R., 2012. EPIC and APEX: model usecalibration and validation. Trans. ASABE 55, 1447-1462.

Wei, Z., Paredes, P., Liu, Y., Chi, W.W., Pereira, L.S., 2015. Modelling transpiration, soil evaporation and yield prediction of soybean in North China Plain. Agric. Water Manage. 147, 43-53.

Williams, D.G., Cable, W., Hultine, K., Hoedjes, J.C.B., Yepez, E.A., Simonneaux, V., Er-Raki, S., Boulet, G., de Bruin, H.A.R., Chehbouni, A., Hartogensis, O.K., Timouk, F., 2004. Evapotranspiration components determined by stable isotope, sap flow and eddy covariance techniques. Agric. Forest Meteorol. 125, 241-258.

Wu, Y., Liu, T., Paredes, P., Duan, L., Pereira, L.S., 2015. Water use by a groundwater dependent maize in a semi-arid region of Inner Mongolia: evapotranspiration partitioning and capillary rise. Agric. Water Manage. 152, 222-232.

Yakima Chief, 2013. Hop Varietal Guide. http://www.uvm.edu/extension/cropsoil/ wp-content/uploads/Hop-Varietal-Guide-2013pdf

Zanoli, P., Zavatti, M., 2008. Pharmacognostic and pharmacological profile of Humulus lupulus L. J. Ethnopharmacol. 116, 383-396.

Zhang, B., Liu, Y., Xu, D., Zhao, N., Lei, B., Rosa, R.D., Paredes, P., Paço, T., Pereira, L.S. 2013. The dual crop coefficient approach to estimate and partitioning evapotranspiration of the winter wheat-summer maize crop sequence in North China Plain. Irrig. Sci. 31 (6), 1303-1316.

Zhao, N.N., Liu, Y., Cai, J.B., Rosa, R., Paredes, P., Pereira, L.S., 2013. Dual crop coefficient modelling applied to the winter wheat-summer maize crop sequence in North China Plain: basal crop coefficients and soil evaporation component. Agric. Water Manage. 117, 93-105. 